\title{
Alaska Division of Geological \& Geophysical Surveys Annual Report 2019
}

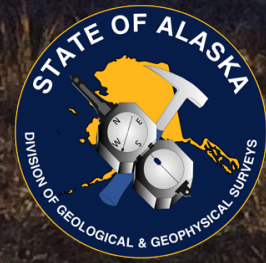




\title{
STATE OF ALASKA
}

Mike Dunleavy, Governor

\section{DEPARTMENT OF NATURAL RESOURCES}

\author{
Corri A. Feige, Commissioner
}

\section{DIVISION OF GEOLOGICAL \& GEOPHYSICAL SURVEYS}

Steve Masterman, State Geologist and Director

Publications produced by the Division of Geological \& Geophysical Surveys (DGGS) are available for free download from the DGGS website (dggs.alaska.gov). Publications on hard-copy or digital media can be examined or purchased in the Fairbanks office:

Alaska Division of Geological \& Geophysical Surveys

3354 College Rd., Fairbanks, Alaska 99709-3707

Phone: (907) 451-5010 Fax: (907) 451-5050

dggspubs@alaska.gov|dggs.alaska.gov

\section{DGGS publications are also available at:}

Alaska State Library,

Historical Collections \& Talking Book Center

395 Whittier Street

Juneau, Alaska 99811

Alaska Resource Library and Information Services (ARLIS)

3150 C Street, Suite 100

Anchorage, Alaska 99503

\section{Suggested citation:}

DGGS Staff, 2020, Alaska Division of Geological \& Geophysical Surveys Annual Report 2019: Alaska Division of Geological \& Geophysical Surveys Annual

Report 2019. doi.org/10.14509/30285
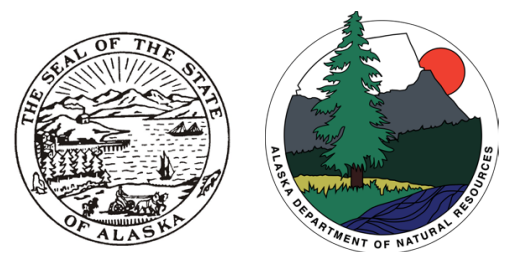

Cover (front and back). DGGS scientists collect ground control for an airborne lidar survey in support of snow avalanche research along the Snettisham transmission line near Juneau, Alaska. Photo: Katreen Wikstrom Jones, DGGS. 


\section{Contents}

Challenges \& Issues.....................................

Organization ..............................................

Mapping …................................................ 6

By the Numbers.........................................

Energy Resources........................................ 8

Mineral Resources........................................ 11

Engineering Geology ................................ 15

Volcanology.................................................. 22

Geologic Information Center .................25

Alaska Geologic Materials Center..........27

Staff Transitions ............................................29

Relationships with Other Agencies........ 31

\section{MISSION}

Determine the potential of Alaskan land for production of metals, minerals, fuels, and geothermal resources, the locations and supplies of groundwater and construction material, and the potential geologic hazards to buildings, roads, bridges, and other installations and structures (AS 41.08.020).

\section{BACKGROUND}

The Alaska Division of Geological \& Geophysical Surveys (DGGS) is part of the Alaska Department of Natural Resources (DNR) and is organized into six program sections: Energy Resources, Mineral Resources, Engineering Geology, Volcanology, Geologic Information Center (GIC), and the Alaska Geologic Materials Center (GMC). In FY2019, the division had 36 full-time permanent positions, one part-time position, and 8 non-permanent positions. The total FY2019 expense budget for the division was $\$ 8.31$ million, consisting of $\$ 3.56$ million state general fund receipts, \$2.1 million federal receipts, \$2.14 million capital improvement projects and interagency receipts, and $\$ 529$ thousand in designated general fund and publication sales. DGGS maintains a website at dggs.alaska.gov, which provides access to its publications and digital data as well as to all predigital USGS publications on Alaska geology. DGGS also administers websites for the Alaska Volcano Observatory (avo.alaska.edu), the Alaska Seismic Hazards Safety Commission (seismic.alaska.gov), and the Alaska Geospatial Council (agc.dnr.alaska.gov).

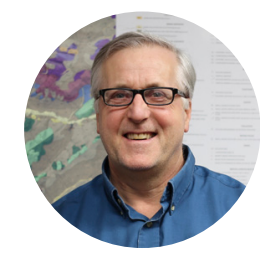

MESSAGE FROM THE DIRECTOR

Another year has flown by, and even though I have said it before, I continue to be amazed by the impact of the work by the staff at Alaska's geological survey, or DGGS as we call it. Whether it's core workshops on oil and gas plays, mapping coastal flooding and erosion, issuing volcano eruption alerts to communities and aviators, mapping Alaska's mineral belts, or educating Alaskans about arsenic and radon, the work done by DGGS touches the lives of all Alaskans.

DGGS provides geologic information to help industry discover and develop Alaska's energy and mineral resources. DGGS also informs on geologic hazards, general geology, construction materials, and groundwater resources, which are critical to sustaining our communities and developing our natural resources. We view public geologic information as a key element in unlocking our natural resources, protecting communities, and helping grow Alaska's economy.

This report is a brief, annual summary of the work of DGGS. Some notable 2019 accomplishments include:

DGGS staff safely completed over 1,093 days of fieldwork, and 2,500 square miles of geologic mapping without a lost-time accident.

DGGS petroleum geologists conducted fieldwork in the North Slope Foothills and near the 1002 area of ANWR. Results were shared during a two-day industry tour.

The GMC held a core-scanning workshop where over 80 attendees reviewed state-of-theart scanning technologies and results from vendor scans of GMC samples.

DGGS began mapping for the Earth MRI project. This new federal critical minerals initiative was accompanied by significant state and federal funding that enabled us to quadruple the area geologically mapped each year, and resume collection of airborne geophysical data.

DGGS conducted auger drilling for sand and gravel resources on the North Slope in a joint BLM-SOA program that was partially funded by the ASTAR project.

Indications are that 2020 will be another impactful year; projects already in the planning stages include

Core drilling four stratigraphic holes into Brookian reservoir and source rocks.

Expansion of data collection under ASTAR, with additional data acquisition in sand and gravel resources, water resources, coastal hazards, and petroleum geology.

Completion of geologic mapping of the Tanacross Quadrangle at 1:100,000 scale.

Adding multi-spectral cameras to the lidar instrument to acquire thermal, RGB, and infrared images.

Additional core workshops at the GMC to advance industry understanding of the Brookian reservoir rocks on the North Slope.

These are just a few of the notable DGGS achievements during the last year, and a glimpse of the very busy year we have ahead. I encourage you to read this report and learn more about us, our people, activities, products, and impacts. We hear from our constituents that the information we produce benefits the state by facilitating the discovery and commercialization of the state's undiscovered oil, gas, coal and mineral resources, and by protecting Alaskans from geologic hazards. We hope this report gives you a better understanding of that work.

Respectfully,

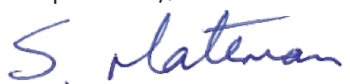

Steven S. Masterman

State Geologist \& Director 


\section{CHALLENGES \& ISSUES}

DGGS faces numerous challenges that require the strategic allocation of available resources to balance the needs of the broader state economy with those of local communities, all while ensuring that we fulfill our statutory mission.

\section{David and Goliath}

DGGS is too small an organization relative to Alaska's size. This is the root cause of the majority of our challenges and translates into being unable to fulfill our mission in a functional amount of time. As an example, the geologic mapping rate over the last 20 years indicates it will take DGGS at least another 400 years to complete a geologic map of the state at a 1-inch to 1 -mile scale. While recent increases in funding have reduced this time horizon, it will still take 100-200 years to complete geologic mapping of our state. Our rates of data acquisition need to accelerate across all mission areas for the state to achieve the potential inherent in its energy and mineral resources - and to assist communities with hazard planning — all in a meaningful timeframe.

\section{Energy Resources}

\section{Providing sufficient geologic information on all} of Alaska's oil and gas basins to support development: As oil companies have transitioned to smaller exploration departments, and as more independent oil and gas companies participate in Alaska, there is an increasing need for publicly available geological information on the petroleum geology of Alaska's oil and gas basins. Maintaining access to existing information and providing new data on established and frontier basins are crucial for future oil and gas production.

Providing timely information in sufficient volume to support exploration of new oil and gas plays: The USGS recently revised their NPRA oil and gas assessment, and concluded that there are billions of barrels of oil yet to be discovered. However, the North Slope is a mature hydrocarbon basin and, like all mature hydrocarbon basins, the "easy" prospects were drilled and tested early. The untested, remaining plays require new geologic research and investment to maintain discovery and production rates. This new geologic information is the key to advancing understanding of the petroleum systems and ensuring new resource discoveries.

\section{Providing updated and comprehensive informa-} tion on geothermal resources: DGGS terminated its geothermal program following 2015 budget reductions. With technology changes and high energy prices, geothermal projects are increasingly attractive long-term energy solutions. New and comprehensive data availability will facilitate development of our geothermal resources.

\section{Mineral Resources}

Providing comprehensive geological, geochemical and geophysical datasets covering Alaska's mineral belts: These data reduce the cost of entry into new areas-a critical factor considered by industry when allocating exploration resources-and are crucial in attracting new exploration spending. Many other political jurisdictions continue to invest aggressively in publicly available geological, geophysical, and geochemical data. Alaska competes head-to-head with these jurisdictions for industry exploration dollars. A lack of similar surveys in Alaska is reducing the state's attractiveness for mineral exploration dollars and impacts Alaska’s competitiveness.

Providing information on construction materials: Construction materials are in critically short supply in numerous areas of the state, and the lack of affordable basic construction materials can dramatically affect project economics.

\section{Public Safety and Community Resilience}

Providing basic statewide geologic hazards data: Despite Alaska's abundance of geologic hazards, such as earthquakes, tsunamis, volcanoes, landslides, avalanches, erosion, and others, there is a grave lack of systematic, statewide data for these natural hazards. Communities, residents, project proponents, and managers alike suffer from this lack of basic data.

\section{Providing community-scale information to guide} community resiliency: Geologic information is needed 
in a large number of communities for resiliency efforts. These data are essential for coastal and river communities, which can be impacted by thawing permafrost, erosion, storm surges, landslides, sea-level change, and changes in the hydrologic system.

Providing data before they are necessary to manage crisis situations: Data collection and hazard assessments typically occur following a natural disaster. There is ample evidence that systematic hazard assessments collected before natural disasters occur help mitigate impacts from natural events.

\section{Climate Impacts}

Providing community and statewide data to inform decision-making in response to a warming Arctic: As geologists, we know that Alaska has been warming since the last glacial maximum, roughly 25,000 years ago, when mammoths roamed Alaska and glaciers covered much more of our state. Data tell us that Alaska's glaciers are still shrinking and the permafrost is warming. Mapping areas prone to ground failure from past and predicted changes is necessary to mitigate impacts. Impacts will be most extreme in coastal, low-lying areas, and areas that will be destabilized by thawing permafrost. The need for basic data at community and state scales is greater than our current capacity to provide.

\section{Coastal Mapping}

Providing the necessary data on coastal and nearshore areas, and other areas of critical need: Alaska is the nation's only Arctic state, and its strategic importance is growing. The expansion of Arctic shipping lanes from Asia to Europe highlight the paucity of basic coastal and maritime data along Alaska's western and northern coasts. With over 50 percent of the nation's tidal shoreline, mapping Alaska's coastline and vast exclusive economic zone is no small task. This mapping data is critical for coastal communities, transportation, maritime safety, fishing, mineral and energy projects, and national security.

Geologist Janet Schaefer (AVO/DGGS) collects sparse ash encased in ice and snow on the south flank of Shishaldin volcano. Photo. Wyatt Mayo.

\section{Leveraging Geologic data and Materials}

Our ability to provide geologic data to exploration and development industries will be tested as users demand both comprehensive information and rapid delivery. The Geologic Materials Center (GMC) is a key component of these efforts and is a "first stop" for oil and gas and mineral exploration companies.

\section{Leveraging the GMC collection by expanding} services: The state's archive of geologic materials represents billions of dollars of acquisition and preservation costs. Providing efficient and comprehensive access to this collection is critically important for viable exploration programs, for both seasoned and new Alaska exploration companies. Any one piece of core from this archive has the potential to identify a resource prospect that could bring billions of dollars of revenue to the state. Expanding the services offered to include optical and physical property scans of the core is an emerging challenge, and an opportunity to leverage the collection.

DGGS must continue developing and optimizing its data acquisition, storage, and distribution methods to enhance information dissemination: Digital mapping techniques, changes in database design, vast volumes of data, and changing methods of accessing data are a challenge to DGGS' ability to meet an increasingly diverse and advanced customer base. Paper maps and reports are no longer sufficient; digital maps, databases and geodatabases, web services and portals, social media, and interactive online maps are among our growing list of distribution methods that are demanded in an increasingly electronic world.

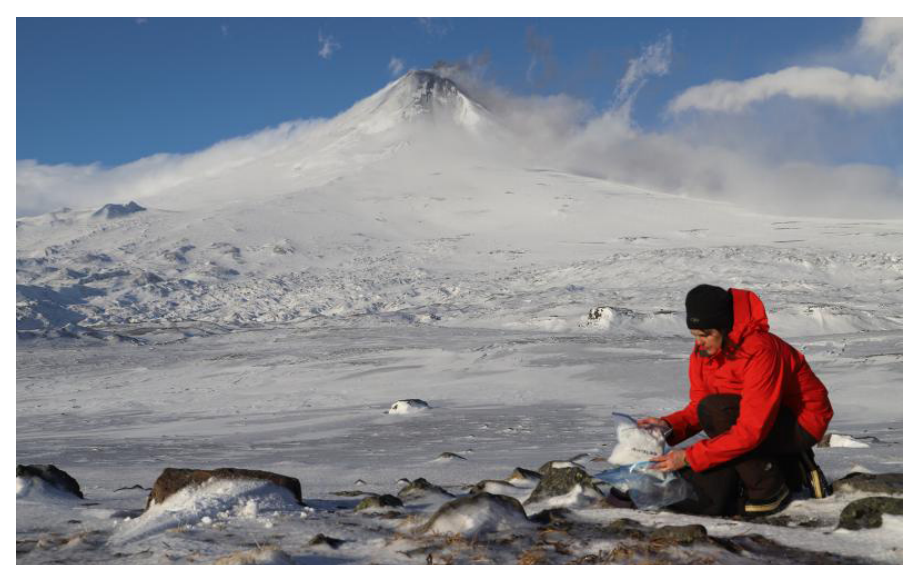




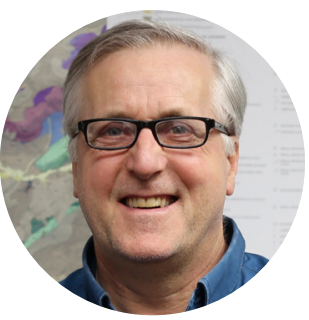

Steve Masterman Director/Chief Geologist

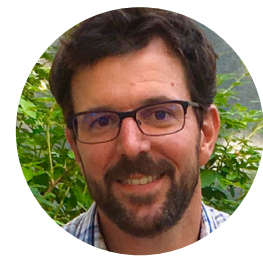

Ken Papp

Division Operations Manager

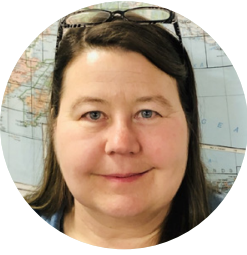

De Anne Stevens

Engineering Geology Section Chief Geologist V

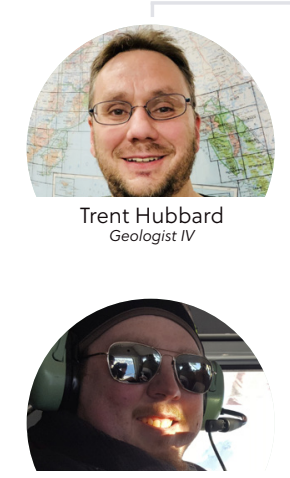

Tyler Stokes

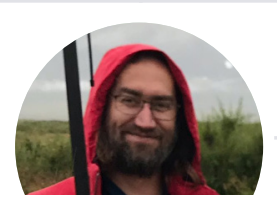

Ronnie Daanen Geologist IV

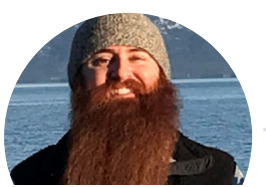

Barrett Salisbury Geologist IV

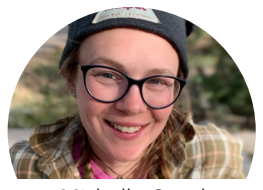

Michelle Gavel Geologist II (LTNP)

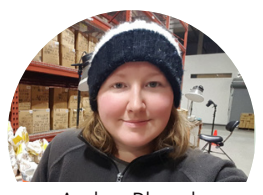

Amber Rhoads

Nat ResTech I (LTNP)

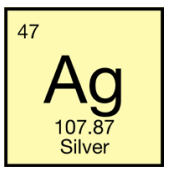

Zachary Spath

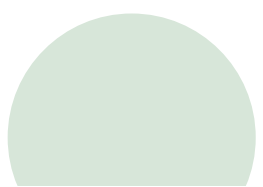

GIS Analyst II (LTNP)
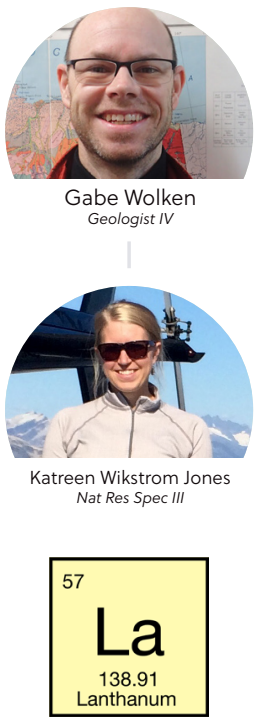

Brayton Keith College Intern

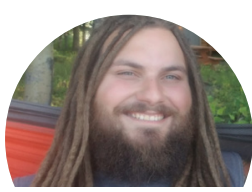

Nathan Reams College Intern

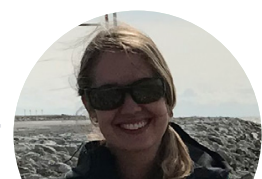

Jaquelyn Overbeck Geologist IV

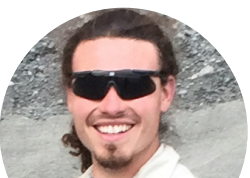

Mark Turner

Geologist I (ITNP)

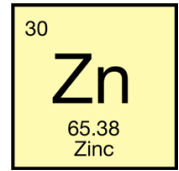

Katie Miller College Intern

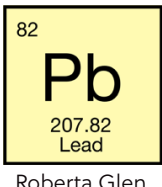

Roberta Glen

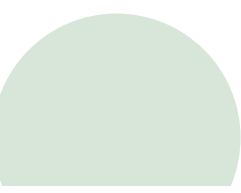

Geologist II (LTNP)

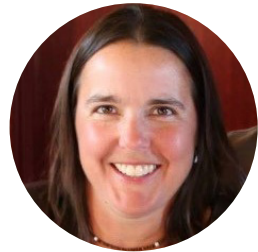

Janet Schaefer Volcanology Section Chief Geologist V

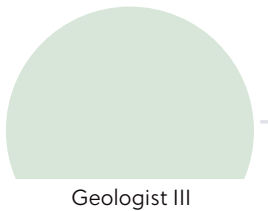
Vacant*

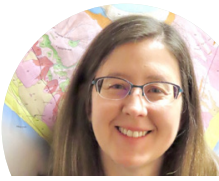

Cheryl Cameron (n)

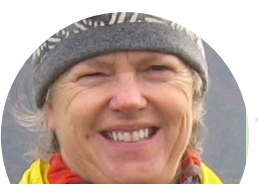

Kate Bull Nat Res Tech III (LTNP)

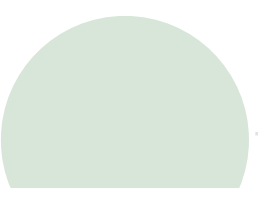
Geologist

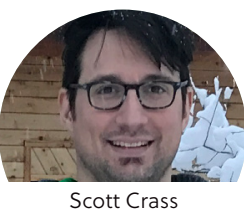
Scott Crass
Analyst/Prog IV

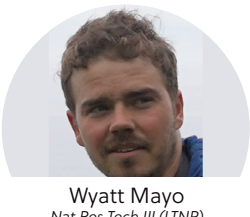

Nat Mayo

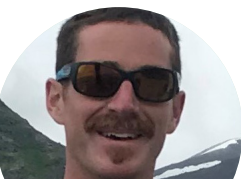

Malcolm Herstand Nat Res Tech III (LTNP)

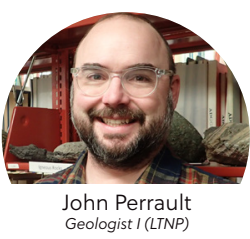

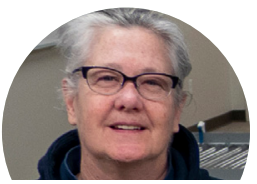

Jean Riordan Geologist IV

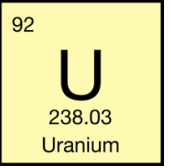
Chris Ramey

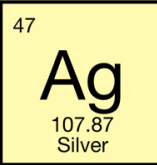

Oralee Nudson Systems Programmer i/l

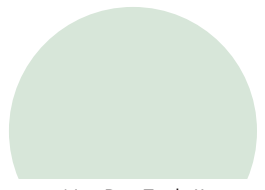

Nat Res Tech II Vacant*

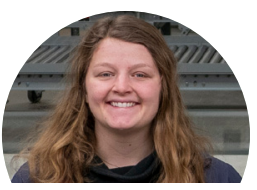

Monica Flemming College Intern

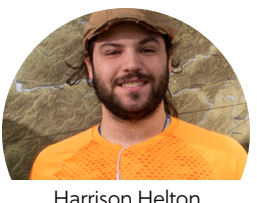

Harrison Helton College Intern 


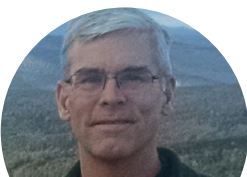

Mike Hendricks GIS Analyst III

Thomas Cerny Microcomputer/Netwo

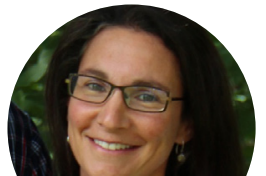

Sue Seitz Analyst/Prog IV

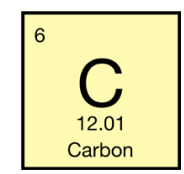

Simone Montayne Geologist III

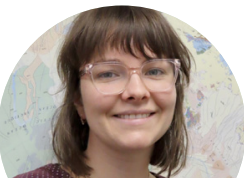
Kristen Janssen
Pub Specialist II

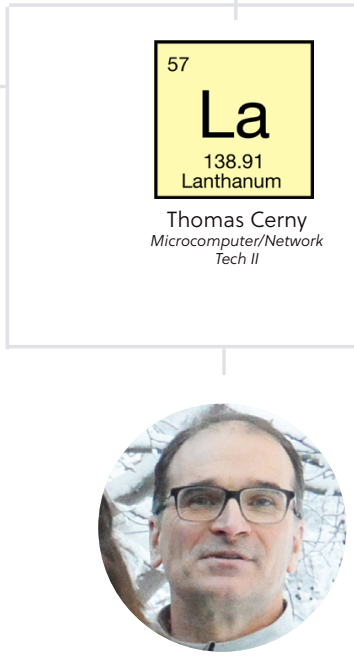

Dave LePain

Energy Resources Section Chief Petroleum Geologist I
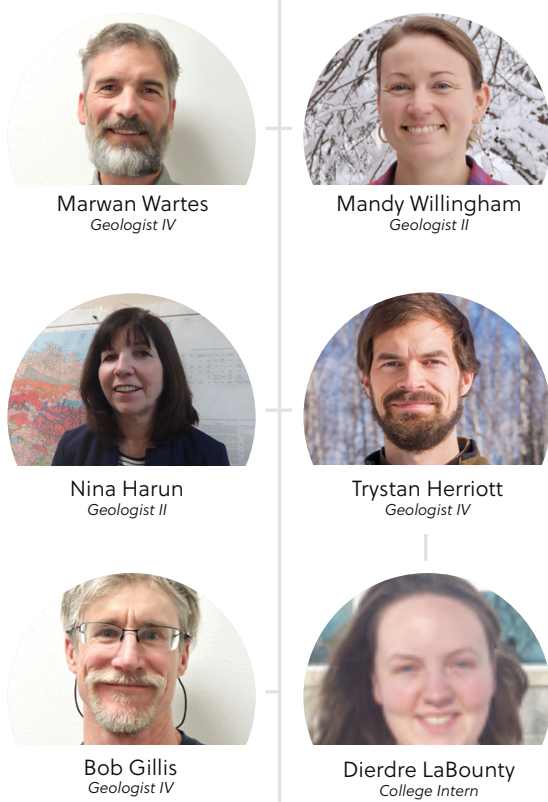

Mandy Willingham

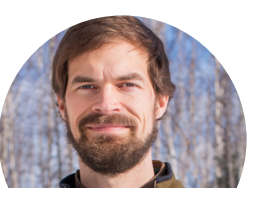

Trystan Herriott

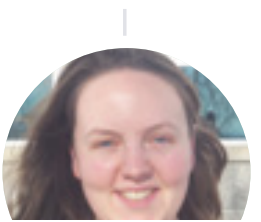

Dierdre LaBounty College Intern

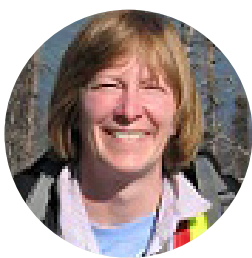

Melanie Werdon

Minerals Resources Section Chief Geologic Scientist I

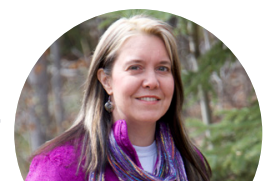

Jennifer Athey Geologist IV

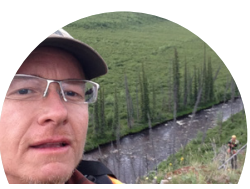

Chris Wyatt

Ceologist II (LTNP)

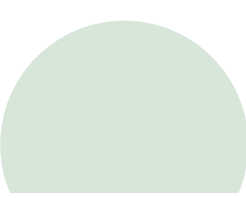

NRT I (LTNP)

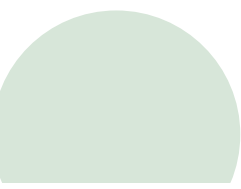

Geologist li/II vacant

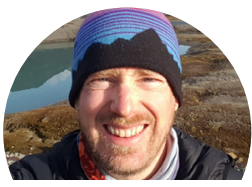

Travis Naibert Geologist I

Evan Twelker Geologist IV

Alicja Wypych Geologist III

Gina Graham

Geologist II

Karri Sicard
Geologist III

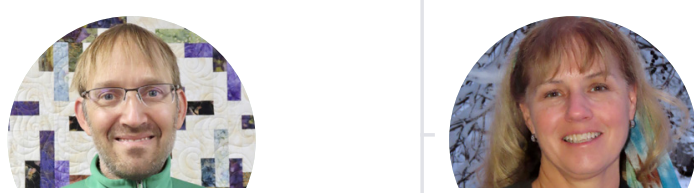
Abraham Emond
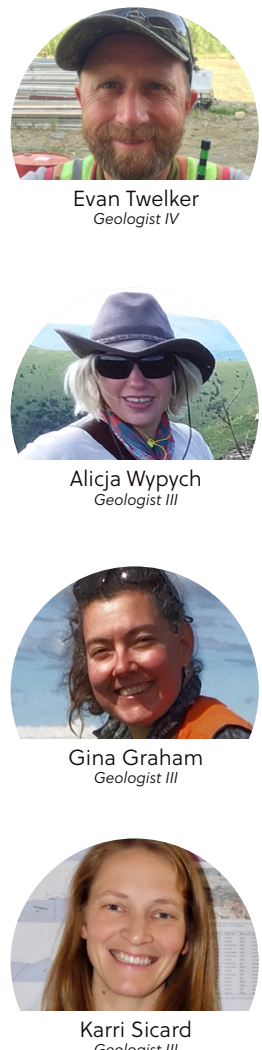

Linda Natrop

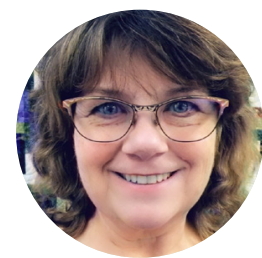

Shelly Showalter Administrative Officer /

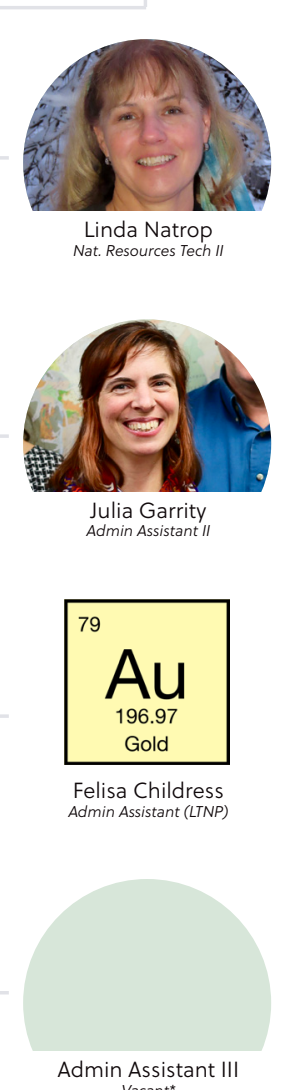

Admin Assistant III

*This is a recently added position that is being actively recruited for 


\section{MAPPING}

\section{Geologic}

Detailed geological and geophysical maps of Alaska at scales needed for resource exploration, landuse management, and geologic-hazards assessment are currently available for only about 20 percent of the state, but our field programs are increasing this coverage gradually each year. DGGS prioritizes the selection of new mapping areas in consultation with other state agencies, appropriate state boards and commissions, its Geologic Mapping Advisory Board, industry resourceinterest groups, and other stakeholders. The survey is committed to delivering the results of its extensive field mapping programs to the public in a timely manner. In FY2019 DGGS published geologic mapping for a total of 1,311 $\mathrm{mi}^{2}$ of Alaskan lands. Over the past 10 years, DGGS has published an annual average of $2,836 \mathrm{mi}^{2}$ of peer-reviewed geologic mapping.

\section{Geophysical Surveys}

Much of Alaska's lands that have high mineralresource potential have poorly exposed geology due to tundra and tree cover. Airborne geophysical surveys measure physical properties of the earth that correspond to various geologic features whose measurements are not affected by vegetation. Airborne geophysical survey data are invaluable for guiding subsequent ground-based

\section{Area of Alaska Geologically Mapped at Inch-to-Mile Scale}

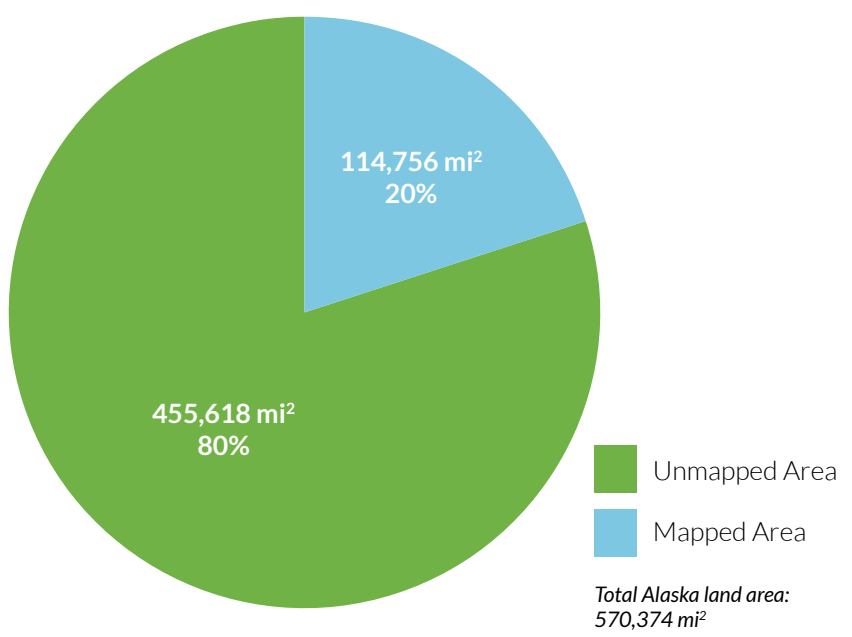

geologic mapping, sampling, and associated mineralassessment work. Only about 28 percent of prioritized mineral-bearing state lands have geophysical survey coverage, and DGGS is committed to acquiring data in the remaining areas of the state that have high mineralresource potential, subject to availability of funding.

In FY2017, DGGS contracted with the U.S. Geological Surveys (USGS) for a new federally-funded airborne geophysical survey covering about 5,292 $\mathrm{mi}^{2}$ in the Porcupine River area in northeastern Alaska. DGGS also partnered with the University of Alaska Fairbanks and the USGS to fly four additional surveys for geologic-hazard assessments, covering a total of 185 $\mathrm{mi}^{2}$. Both of these datasets were released to the public in FY2019.

The state-funded Strategic and Critical Minerals (SCM) project (FY2013-2015) allowed DGGS to publish annually more than twice the amount of airborne geophysical data that had been published in prior years under the state's annually funded Airborne Geophysical/Geological Mineral Inventory (AGGMI) program. Budget cuts in FY2016 eliminated both the SCM project and AGGMI program, and lack of state funding meant that no further state-funded airborne geophysical surveys of mineral districts could be planned. The federal Earth MRI critical minerals program was funded by the U.S. Congress in FY2019, and is anticipated to be a 10-year project to acquire airborne geophysical surveys, geologic mapping, and lidar over areas of the nation that have potential for critical minerals. DGGS has been contracted by the USGS to manage the federal geophysical contracts covering large portions of Alaska's mineral districts. In FY2019, a state capital project provided one year of state matching funds to further

for spring/summer 2020 in the Yukon-Tanana Uplands, with publication of survey data in early FY2021. 
FY19 Division Budget

(in thousands of dollars)

$\$ 2,000$

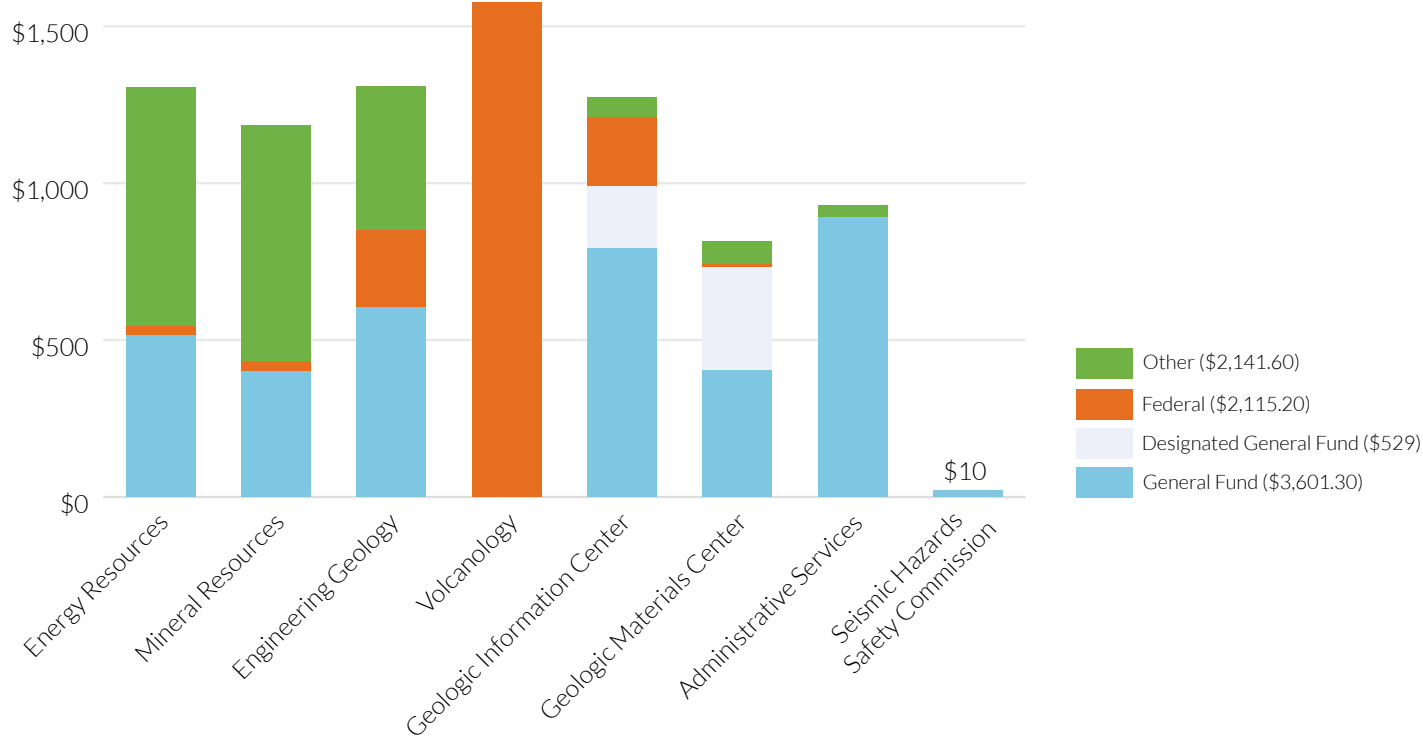

Published Reports

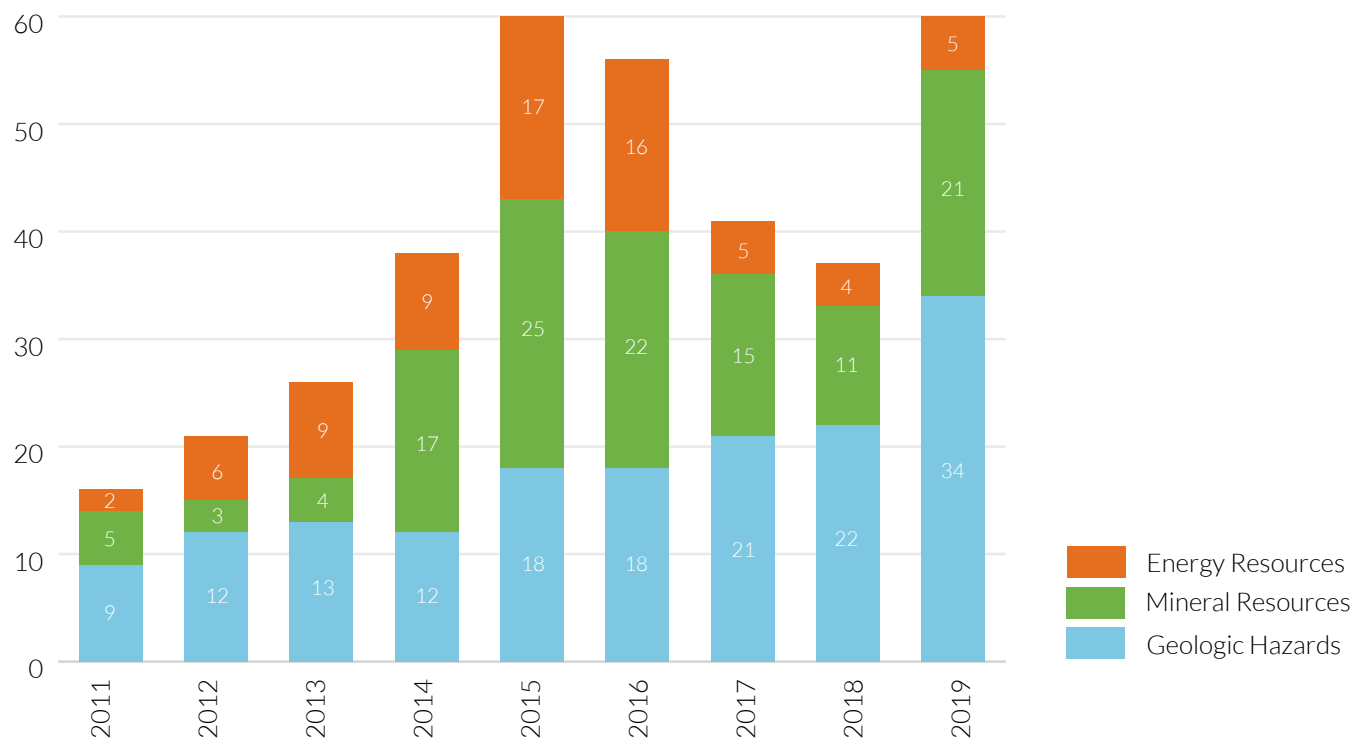




\section{ENERGY RESOURCES}

Alaska's Statewide Energy Resource Assessment program generates new geologic information about the state's oil, natural gas, coal, and geothermal resources and presents this information to the industry, public, and state and federal agencies through formal reports and presentations. DGGS collaborates with the Alaska Division of Oil \& Gas (DOG) to incorporate subsurface data in the interpretation and analyses of complex depositional and hydrocarbon systems and tectonic provinces.

In FY2019, the Energy Resources Section submitted separate, successful proposals to the USGS STATEMAP program and the oil and gas industry to partially fund bedrock geological mapping in the Big Bend of the Chandler River area south of Umiat and petroleum geology studies on the North Slope, respectively. Industry support and collaboration continued as the section led a two-day-long field tour for industry to examine key exposures of the Nanushuk, Torok, Seabee, Prince Creek, Sagavanirktok, and Canning Formations on the central North Slope to highlight their petroleum potential. DGGS also organized and led a two-day-long core workshop and poster session for industry at the Alaska Geologic Materials Center focusing on the depositional setting and reservoir potential of the Nanushuk Formation in the eastern NPRA.

View toward the northeast showing interbedded sandstones and mudstones comprising deposits of a delta lobe preserved in the lower Nanushuk Formation at Slope Mountain. Deltaic deposits similar to these host large accumulations of oil in northeastern NPRA and Colville Delta area. The Trans-Alaska Pipeline is visible near the right, center edge of the photograph.

\section{DATA DISTRIBUTION AND PUBLICATIONS}

DGGS has accumulated a vast amount of relevant petroleum-related geologic data over the past few decades and continues to gather new data. Prior to the FY2019 field season, the Energy Resources Section successfully collaborated with other DGGS professionals and IT support to develop and implement digital field data capture methodology using tablet devices. Progress continues on creating a division-wide energy resources geodatabase. Once finished, this will allow industry and the public to search for relevant geologic data from throughout the North Slope, Cook Inlet, and other Alaska frontier basins.

In FY2019, the section published 11 DGGS reports on the petroleum geology of the North Slope and Cook Inlet basin, and two reports in international peer-reviewed journals addressing the provenance of sandstones in Cook Inlet basin and the uplift history of the Talkeetna Mountains. Lastly, DGGS geologists delivered seven oral presentations on aspects of the petroleum potential of the North Slope.

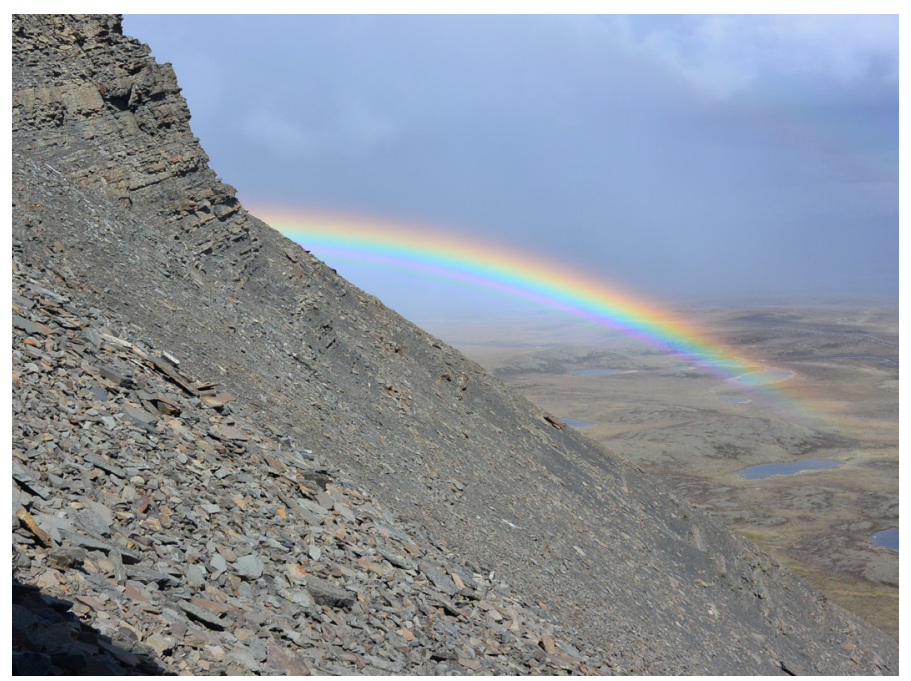




\section{FIELD WORK \\ In 2019, the Energy Resources Section completed:}

12 days of helicopter-supported fieldwork in the Big Bend area south of Umiat mapping bedrock formations in outcrop that host large oil accumulations in the subsurface of the eastern National Petroleum Reserve-Alaska (NPRA) and Colville River Delta region

10 days of helicopter-supported fieldwork on the North Slope characterizing the petroleum reservoir potential of the Nanushuk and Torok Formations west of the Dalton Highway

10 days of helicopter-supported fieldwork evaluating petroleum systems east of the Dalton Highway, including the 1002 area of Alaska National Wildlife Refuge (ANWR)

\section{A large structure-from-motion survey of the Nanushuk and Torok Formations at Slope Mountain for} use as a base for mapping reservoir-scale sand bodies, and in modeling their seismic response (seismic forward modeling) to better understand the seismic signature of oil reservoir sands in the subsurface at Willow and Pikka

10 days of fieldwork mapping bedrock geology in the eastern Alaska Range for improved understanding of the petroleum potential of the Copper River basin

Reservoir archetype summaries for several Brookian formations on the North Slope (Fortress Mountain, Torok, Seabee, and Sagavanirktok) for an ENI-funded project with the Texas Bureau of Economic Geology (BEG). Summary reports were submitted to BEG-ENI

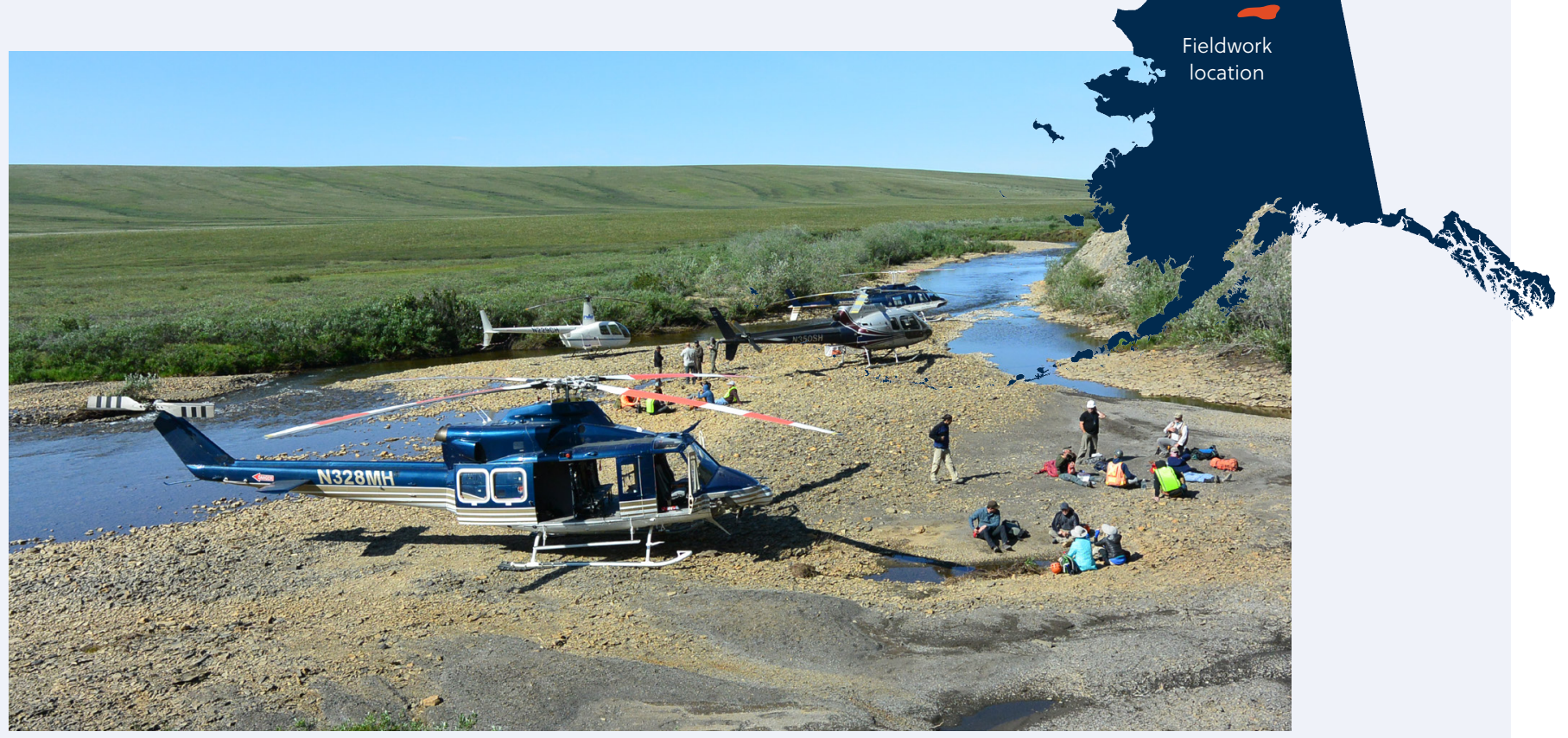

An Energy Resources Section led a two-day field trip for industry focused on key outcrops of the Nanushuk, Torok, Seabee, Canning, and Sagavanirktok Formations. Field tours such as this one spur exploration investment and development success by providing unique, high-quality outcrop analogue information that reduces exploration risk, thereby promoting discovery and production of Alaska's hydrocarbon resources. 


\section{Public Outreach Helps Improve Understanding of North Slope Petroleum Potential}

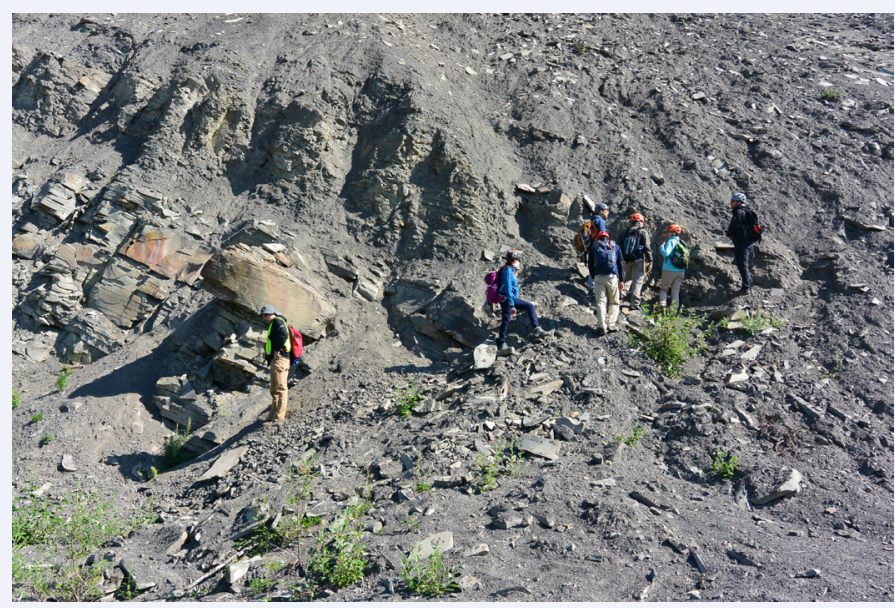

Industry geologists discuss features preserved in deltaic deposits of the lower Nansuhuk Formation exposed on the south flank of Arc Mountain anticline. These geologists participated in a two-day-long tour led by the Energy Section highlighting outcrops of economically significant Brookian formations on the central North Slope. Deltaic deposits similar to these rocks host large accumulations of oil in recently discovered fields in the northeastern NPRA and Colville Delta area.
Northern Alaska continues to garner attention as one of the most prolific hydrocarbon provinces in North America, with 28 billion barrels of oil equivalent discovered to date onshore, and an estimated 30 billion barrels of oil and 181 trillion cubic feet of non-associated gas in undiscovered, but technically recoverable accumulations (U.S. Geological Survey 2012 assessment). Two formations, the Nanushuk and Torok, alone have an estimated mean of 8.7 billion barrels of oil and 25 trillion cubic feet of natural gas. These estimated undiscovered resources are in addition to the 3.3-3.9 billion barrels of oil estimated for recent discoveries at Pikka, Willow, and Smith Bay. Understanding the petroleum geology of this region is critically important for making new discoveries.

To promote new exploration investment and reduce exploration risk, the Energy Resources Section conducts applied research on North

Slope petroleum geology. Results of this work are published as high-quality geological maps and topical research reports that are available to the public at no cost.

The section has a long history of public outreach in the form of core workshops and field tours. In July 2019, the section led a two-day-long tour that focused on key outcrops of the Nanushuk, Torok, Seabee, Canning, Schrader Bluff, and Sagavanirktok Formations in the central foothills that was well attended by industry petroleum geologists and geophysicists. The tour visited outcropping deltaic sand bodies in the Nanushuk and Schrader Bluff Formations that represent valuable analogues for large oil accumulations in the subsurface, and discussed key features that influence reservoir quality. Oil-stained deepwater sandstones in the Seabee Formation and immediately overlying organic-rich clayshales and oil-saturated silicified tuffs in the Hue Shale were examined highlighting their function as a reservoir-source couplet. These tours allow DGGS geologists to share their insights on the region's petroleum geology, and for a general sharing of information among participating industry representatives. Field tours such as this promote discovery and production of Alaska's hydrocarbon resources and spur exploration investment and development success by providing unique, high-quality outcrop analogue information that reduces exploration risk. 


\section{MINERAL RESOURCES}

To attract interest in mineral exploration and to support responsible development of Alaska's mineral endowment, DGGS conducts geological mapping and geochemical and geophysical surveys of the most prospective Alaska lands that are open for resource development. Since 1993 the data products of the Airborne Geophysical/Geological Mineral Inventory (AGGMI) program have been an important component of successful resource exploration programs; products have contributed to the private-sector discovery of more than 22 million ounces of gold in the Salcha RiverPogo and Livengood areas since 2004.

\section{FIELD WORK}

DGGS initiated Alaska's portion of the criticalminerals-focused Earth Mapping Resources Initiative (Earth MRI) project, the purpose of which is to increase the nation's mineral security by conducting geophysical surveys, geologic mapping, and lidar surveys. This primarily federally funded project supplemented with state matching funds will help DGGS Mineral Resources geologists create and disseminate geophysical and geological map products that historically have been

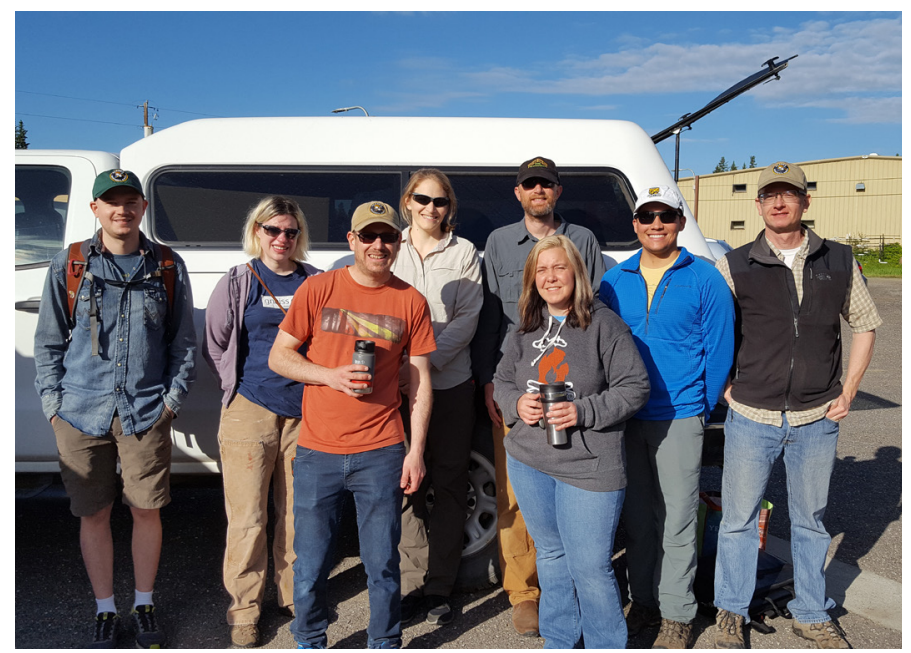

Fieldcrew for the 2019 Minerals Resources field season. $L$ to R: Alec Wildland, Alicja Wypych, Travis Naibert, Karri Sicard, Evan Twelker, Jen Athey, Julian Lopez, Chris Wyatt. shown to stimulate mineral industry interest, staking, and exploration activity in Alaska, as well as increase revenue to the state. The Earth MRI project is being implemented in cooperation with the USGS and is expected to be a 10-year national program funded at greater than $\$ 10$ million per year. In FY2019, Alaska received $\$ 1$ million in federal funds under this program.

In June 2019, DGGS Mineral Resources geologists began their first Earth MRI field project by conducting fieldwork to map $1,900 \mathrm{mi}^{2}$ in the eastern Tanacross region. The project targets a region of the state that has inadequate geologic mapping and the potential to host deposits of rare earth elements and other critical minerals. The area is also prospective for more conventional minerals including copper, gold, and molybdenum, and as of summer 2019, there were four mineral exploration companies actively working in the area. Fieldwork will continue into FY2020, with the final map deliverable due in 2021.

In the summer of 2018 the Mineral Resources Section completed fieldwork for the second phase of a $520 \mathrm{mi}^{2}$ geologic mapping and geochemical sampling project in the northeastern Tanacross quadrangle adjacent to Yukon, Canada. The newly collected field and analytical data have been synthesized and were published as a preliminary geologic map in June 2019. The purpose of this project is to evaluate the area's mineral-resource potential and to create a geologic map to help guide industry exploration efforts. The area contains known porphyry gold-copper-molybdenum systems, which are newly recognized to be spatially associated with high-angle fault systems, many of which can be identified in DGGS airborne geophysical surveys of the area. Remaining work in FY2020 includes publishing the age data and releasing the report of investigation and final rendition of the geologic map.

DGGS completed fieldwork for the second phase of a $430 \mathrm{mi}^{2}$ geologic mapping and geochemical 
sampling project in the Richardson-Uncle Sam gold exploration area northwest of Delta Junction. The area's mineral-resource potential is expected to be high based on known mineral systems and proximity to the Pogo gold mine. The purpose of this project is to integrate geological, geophysical, and mining industry datasets to create an improved geologic map that will guide exploration and help to further determine the area's mineral-resource potential. Ongoing work in FY2020 includes synthesis and interpretation of field data and publishing the supporting geochemical and geochronologic data.

\section{DATA DISTRIBUTION AND PUBLICATIONS}

The section archived and prepared 43 historical airborne geophysical surveys for online publication; of these, 19 were digitally re-released online and DGGS anticipates all "modern" airborne geophysical surveys will be made available online in FY2020. DGGS also gave an invited presentation "Exploration, mapping, environmental monitoring, infrastructure planning Alaska Division of Geological \& Geophysical Surveys geophysics program" at the USGS Airborne Geophysics Workshop and published "Geophysics in Alaska: Alaska Division of Geological \& Geophysical Surveys Information Circular 78," which provides a general overview of our geophysics program for the public. DGGS continued to provide geophysical support for the UAF-DGGS Goldstream Watershed Project by integrating the geophysical data into a $3 \mathrm{D}$ permafrost interpretation and published four engineering-geologyrelated airborne electromagnetic surveys covering 185 $\mathrm{mi}^{2}$ : Goldstream, Yukon Crossing, Yukon Crossing to Fox, and Western Yukon Flats.

The Mineral Resources Section published Alaska's Mineral Industry 2018, an annual summary of activity in the mining sector during the previous calendar year (doi.org/10.14509/30075). The report provides a consistent, factual snapshot of exploration, development, and production of Alaska's mineral resources and serves as the authoritative, historical record of mining in the state.

\section{GEOLOGIC HEALTH HAZARDS}

Naturally occurring radon gas is the second leading cause of lung cancer-after smoking - and an underrecognized health risk in the state. DGGS is preparing deliverables for the final year of an EPA-funded, threeyear project to (1) create an Alaska radon database and compile radon test results from across the state, (2) collaboratively develop an enterprise database model for standardized geologic map data, and (3) create an online radon potential map to help the public visualize the risk from radon in Alaska. The Alaska radon map will be available at the end of 2019 and will be used for radon education and outreach in conjunction with a program that provides free radon testing for Alaskans. DGGS continued to lead geologists and GIS professionals from more than 10 state geological surveys, USGS, and Geological Survey of Canada in the development of a national geologic database model, which is being considered for implementation by the USGS National Geologic Map Database.

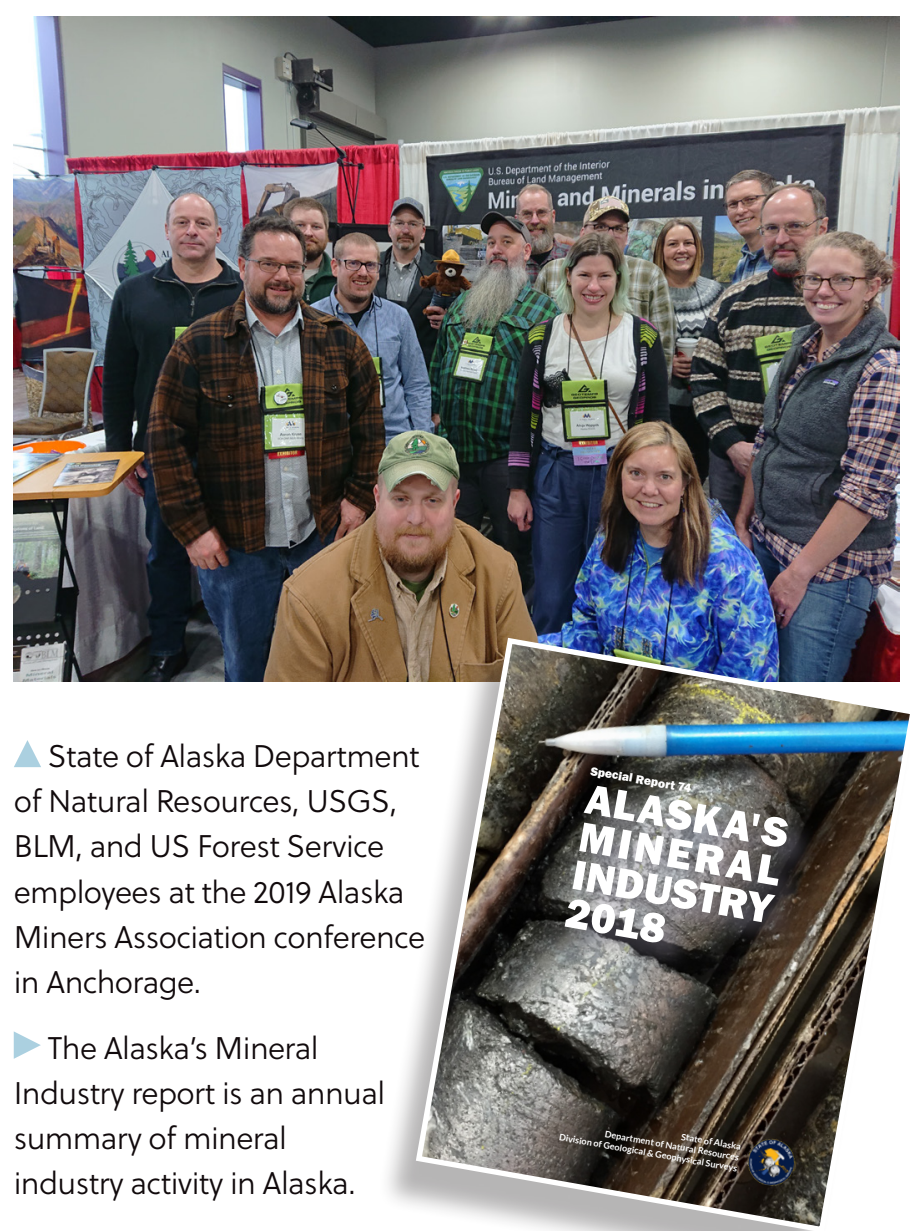




\section{Earth Mapping Resources Iniliative (Earth MIRI)}

The federal Earth Mapping Resources Initiative (Earth MRI) is designed to address the United States' heavy reliance on imports of certain mineral commodities that are vital to the Nation's security and economic prosperity. The U.S. is currently 100 percent reliant on imports for 11 of the most critical minerals, and more than 50 percent reliant on imports for another 17.

\section{The goals of Earth MRI are to:}

- Identify domestic sources for critical minerals

- Produce nationwide geophysical, geological, and topographical surveys of the U.S.

\section{- Partner with state geological surveys, including the Alaska Division of Geological \& Geophysical Surveys (DGGS), to complete these surveys.}

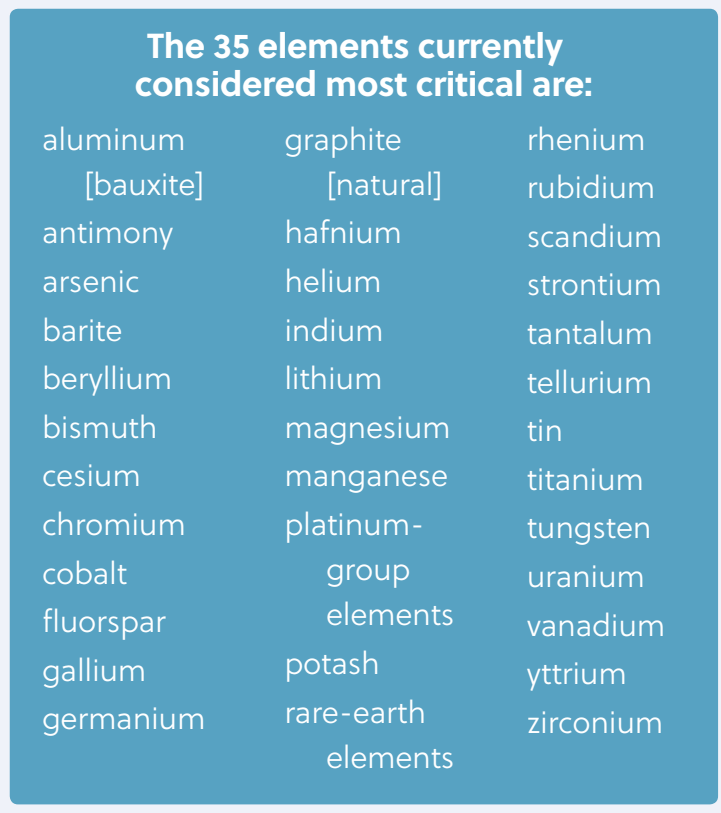

The Earth MRI program, anticipated to last 10 years, was initially funded at $\$ 10$ million per year by the U.S. Congress in federal-fiscal-year 2019 with Alaska receiving $\$ 1$ million in funding. A capital project, appropriated by the Alaska Legislature, provided supplemental, state matching funds to expand Earth MRI work.

Mines in Alaska currently produce the critical minerals germanium and indium, and have historically produced tin, fluorspar, platinum-group elements, antimony, tungsten, and barite. In addition to these elements, Alaska's geology is favorable for locating "as-yet-undiscovered" deposits of additional critical minerals. Earth MRI- and state-funded geophysical surveys, geologic mapping, and resulting datasets and reports will help identify areas of Alaska that have potential for precious and base metals, as well as for critical minerals, which may occur solely as primary commodities, or as co-products or by-products of precious- and base-metal mining.

For the Earth MRI program, DGGS Mineral Resources geologists will be creating and disseminating geophysical and geological map products that historically have been shown to stimulate mineral industry interest, staking, and exploration activity in Alaska, as well as increase revenue to the state. The first area of focus is the YukonTanana Uplands, one of Alaska's premier gold-mining districts that also has high potential for critical minerals. The USGS tasked DGGS with managing Alaska's geophysical surveying contracts. Consequently, initial magnetic and radiometric surveying of about 4,000 $\mathrm{mi}^{2}$ is planned for spring/summer 2020 in parts of the Big Delta and adjacent quadrangles, with publication of survey data by year-end 2020.

In June 2019, DGGS geologists initiated their first Earth MRI geologic mapping project, which covers 1,900 $\mathrm{mi}^{2}$ in the eastern Tanacross Quadrangle. The project targets a region with inadequate-scale geologic mapping and the potential to host deposits of rare earth elements and other critical minerals. The area is also prospective for copper, gold, silver, and molybdenum and, as of summer 2019, there were five mineral exploration companies actively working in the area. DGGS is evaluating the area's mineral-resource potential and will be producing a 1:100,000-scale geologic map, to be published in 2021, that will help guide industry exploration efforts.

Future Earth MRI plans for Alaska include a three- to five-year plan to complete airborne geophysical surveying over the areas in the Yukon-Tanana Uplands that are open to mineral entry, and a five- to seven-year plan to upgrade the scale of geologic mapping to at least 1:100,000. 


\section{Where Geologiy and Positive Health Outcomes Meet}

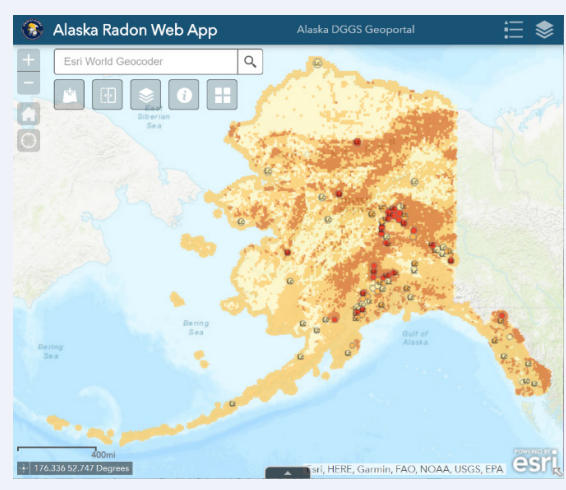

DGGS and the University of Alaska Fairbanks' Cooperative Extension Service are creating a radon database and public visualization tools to better understand radon potential and identify where elevated levels exist in Alaska.

Check out the Radon Web App

geoportal.dggs.dnr.alaska.gov/

portal/apps/webappviewer/index.

html?id $=8 \mathrm{ed} 4 \mathrm{e} 400 \mathrm{e} 2 \mathrm{~d} 9460 \mathrm{c}$

8cf959deb91ee22b

With the culmination of three years of funding from the EPA in fall 2019, DGGS produced results from two significant, but seemingly unrelated projects. Efforts from the first project will help Alaska residents better understand and mitigate the adverse effects of radon gas, which can potentially cause lung cancer. The second project developed an enterprise database to manage geospatial data typically found in traditional geologic maps. The projects are connected by the fundamental notion that knowledge of the earth's rocks, resources, and natural hazards help inform researchers, land managers, industry, decision makers, and the public about ways to improve the health, safety, and well-being of Alaskans. Further, when geologic information is maintained in and accessible from a robust relational GIS database, the data can be used more efficiently and effectively to provide indepth answers to a wide variety of location-based questions about our lands. In this case, information about Alaska's rocks, uranium in soils and sediments, depth to the water table, and results from private indoor-air radon tests have been compiled and displayed in an online, interactive map to help Alaskans visualize their potential risk from naturally occurring radon. The online map's underlying data will be published within the next year.

Radon gas is the second leading cause of lung cancer-after smoking - and an underrecognized health risk in the state. DGGS partnered with the University of Alaska Fairbanks-Cooperative Extension Service to conduct outreach and education with more than 1,500 residents and to distribute free radon test kits as part of the EPA's ongoing State Indoor Radon Grant program. New radon test results from privately owned homes will be updated annually. Although this online map serves as a guide to where radon may occur, indoor radon concentrations can vary greatly from building to building. Indoor-air tests are the only way to know if your home contains radon.

The enterprise geologic database being developed by DGGS is

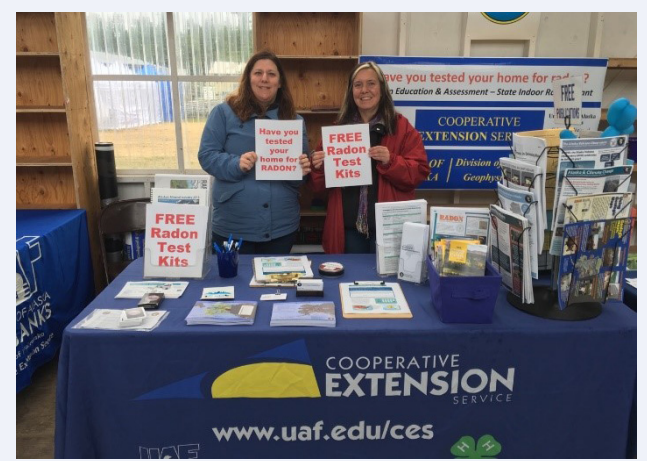

DGGS' Jen Athey (right) educates the public at events around the state about the effects of radon and how to test for it in their homes. based on the USGS Geologic Map Schema (GeMS), a standardized way to encode a single geologic map's GIS data. DGGS led monthly collaborative meetings with other state and national geologic surveys to design and implement a multi-map enterprise geologic database version of the USGS standard. As a result, the USGS National Cooperative Geologic Mapping Program is potentially interested in using the DGGS-GeMS model for storing and serving Earth MRI and national, digital map data to a variety of agency and public users. Work on the database model continues under a cooperative agreement with the USGS. 


\section{ENGINEERING GEOLOGY}

In many areas, Alaska lacks the fundamental geologic data needed to guide the proper development and implementation of building codes, land-use zoning, right-of-way siting, and contingency planning for natural hazards events. Maps and reports produced by the Engineering Geology Section are the front- line source of information about where damage is likely to be greatest and where mitigation efforts should be concentrated. Engineering-geologic maps depicting construction materials resources are useful for building infrastructure to support resource exploration and development, and for locating valuable placer-mineral deposits. Groundwater analysis and aquifer modeling and mapping in oil and gas basins and other areas of high development potential are essential to ensuring an adequate and safe supply of water for development and resource access.

DGGS continues to provide other state and federal agencies with necessary information on geologic hazards for the purpose of land-use planning and decision making. We completed agency reviews regarding potential geologic hazards and engineering-geologic considerations for multiple DNR land disposals, area plans, resource development and subdivision projects, and Environmental Impact Statements.

\section{COASTAL HAZARDS}

Limited sea ice extent in winter 2018-2019 allowed eight significant coastal storms to reach Alaska communities. The DGGS Coastal Hazards Program provided technical assistance to the National Weather Service on potential impacts to communities, and was able to document impacts post-storm using community monitoring on Facebook, new technologies developed by the Alaska Ocean Observing System, and a network of autonomously operating water-level sensors in western Alaska. Documenting these historically anomalous events is critical for understanding Alaska coastal flood risk today and into the future and provides the data necessary for communities to be eligible for many types of federal disaster funding.

Working with more than 40 tribal, city, and corporation entities, the DGGS Coastal Hazards Program developed flooding and erosion data products specifically tailored for the needs of Alaska communities. These products include detailed data on erosion monitoring sites, layered historical aerial and satellite images showing erosion through time, and flood maps showing inundation extents from individual coastal storms. Every Alaska community faces different challenges from flooding and erosion, and by working

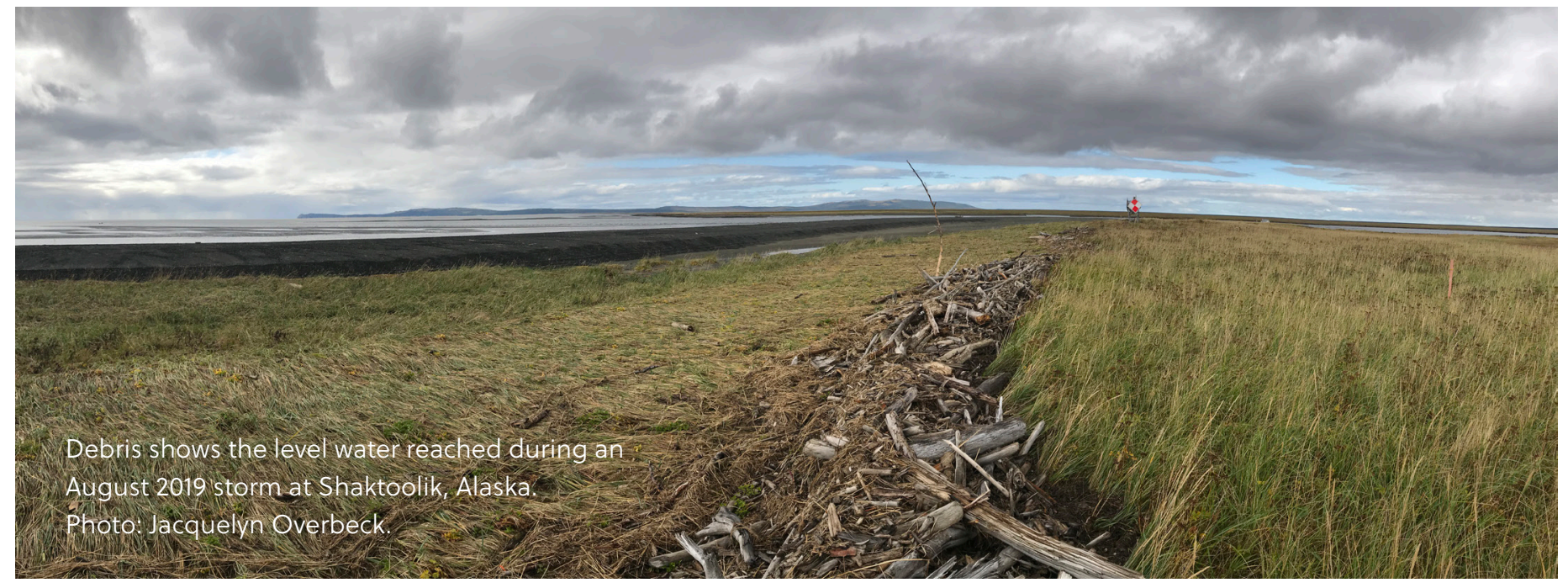


with local entities we are better able to understand local needs and further data collection efforts necessary for mitigation. Newly developed web content provides community-specific data from multiple sources, transmissible over low bandwidth, and in page-size, printable formats. These products are currently available for 16 communities at dggs.alaska.gov/hazards/coastal/ monitoring.html.

The DGGS Coastal Hazards Program successfully advocated for state and federal agencies to fill gaps in data needed to better evaluate coastal flood and erosion hazards for Alaska communities. Maintaining collaboration and communication with more than 20 state, federal, and non-government partners, we assisted in developing the Alaska Coastal Mapping Strategic Plan (due for release April 2020) and associated prioritization survey; the Alaska Water Level Watch collaboration of state and federal agencies, nonprofits, private sector, and

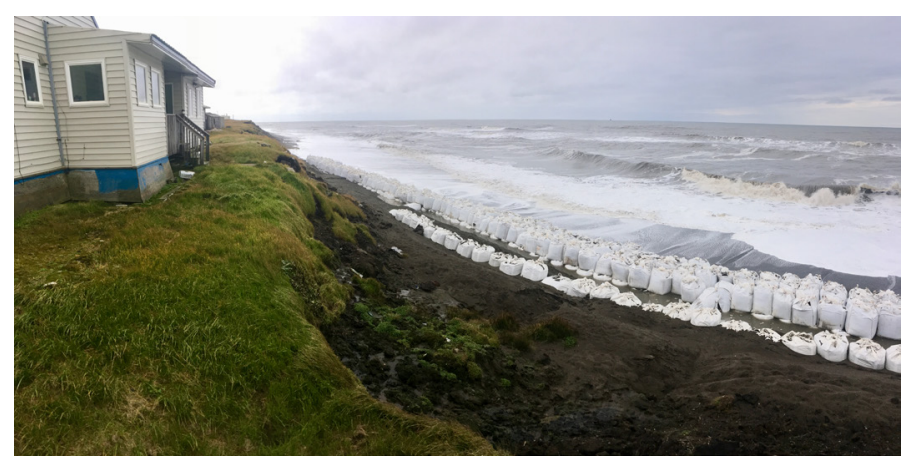

Sandbags are used to help mitigate coastal erosion in Utqiagvik, Alaska during a coastal storm in August 2019. Photo: Jacquelyn Overbeck.

university partners; the Alaska response to the USGS/ NOAA 3D Nation survey; and provided technical guidance to state and federal agencies. Because of these efforts, an additional 200 miles of Alaska coast are being mapped and seven of the remaining 30 gaps in tidal data are being collected this year.
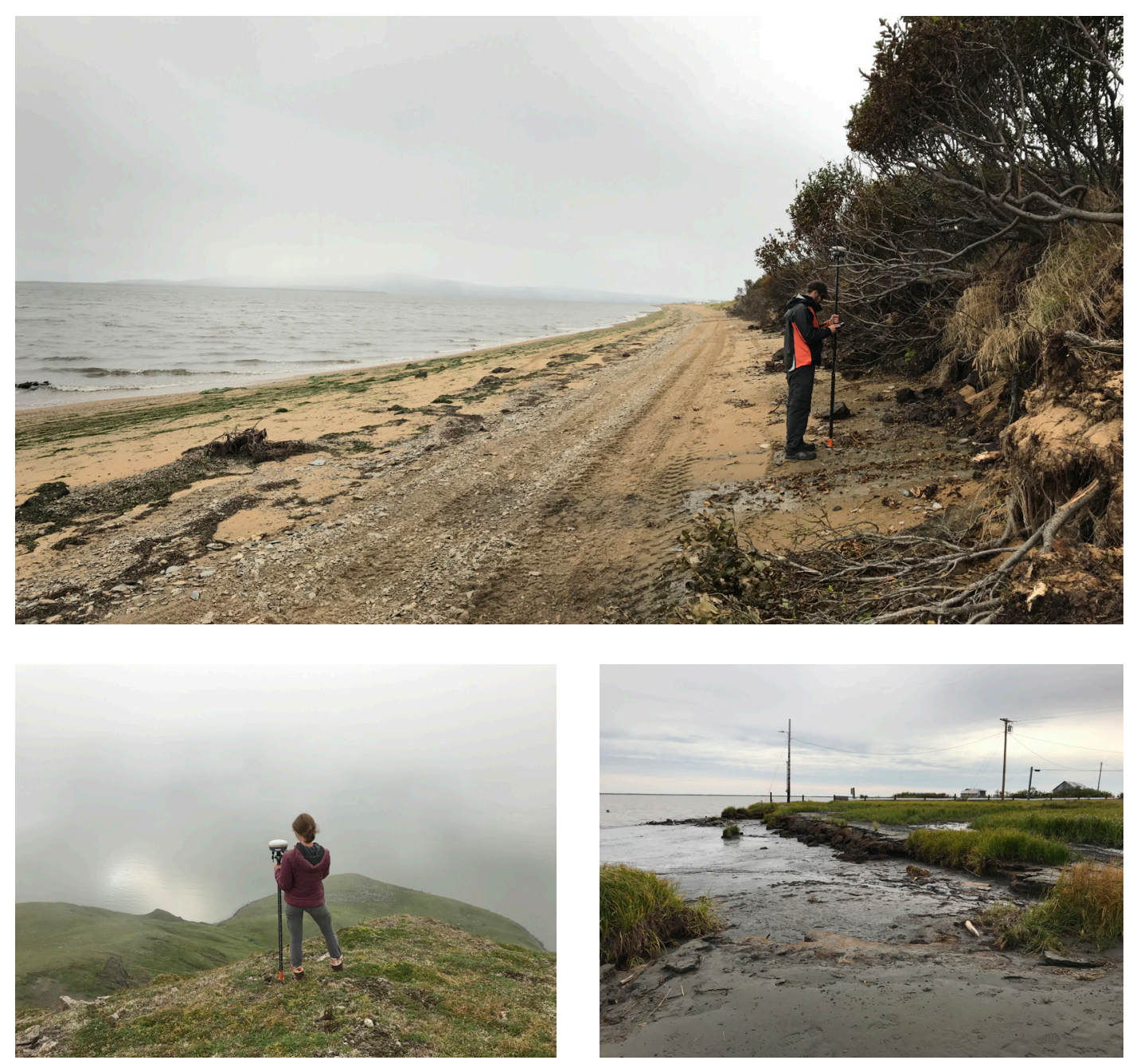

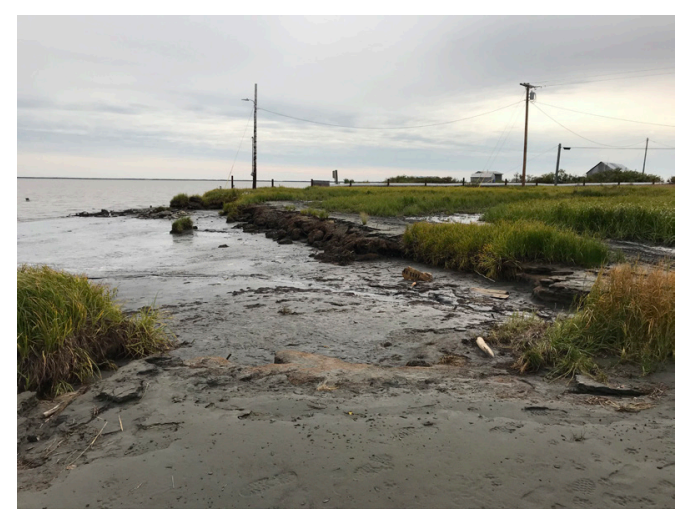

Every Alaska community faces different challenges from flooding and erosion, and by working with local entities we are better able to understand local needs and further data collection efiorts necessary for mitigation.

Top. Repeat GPS surveys show that a recent storm caused significant erosion in Golovin, Alaska. Photo: Katie Miller.

Bottom left. Ground control with GPS surveys allows DGGS to map areas with drones. Photo: Jacquelyn Overbeck.

Bottom right. Erosion at Nunam Iqua threatens community water supply and power poles. Photo: Jacquelyn Overbeck. 


\section{Project Highlight}

\section{Coastal Hazards Mapping and Monitoring for Alaska Communities}

The DGGS Coastal Hazards Program (dggs.alaska.gov/hazards/coastal) is dedicated to providing rural Alaska communities with highquality coastal mapping and monitoring for mitigating flood and erosion hazards. Although most Alaska communities are well aware of the hazards they face, communicating the urgency and magnitude of the hazards to people outside the community requires data. These rural coastal communities have historically lacked the baseline data needed to quantify historical erosion and maximum flood levels.

Whether developing an update for a local hazard mitigation plan or applying for a grant to upgrade coastal infrastructure, DGGS strives to provide timely and accurate data to community members

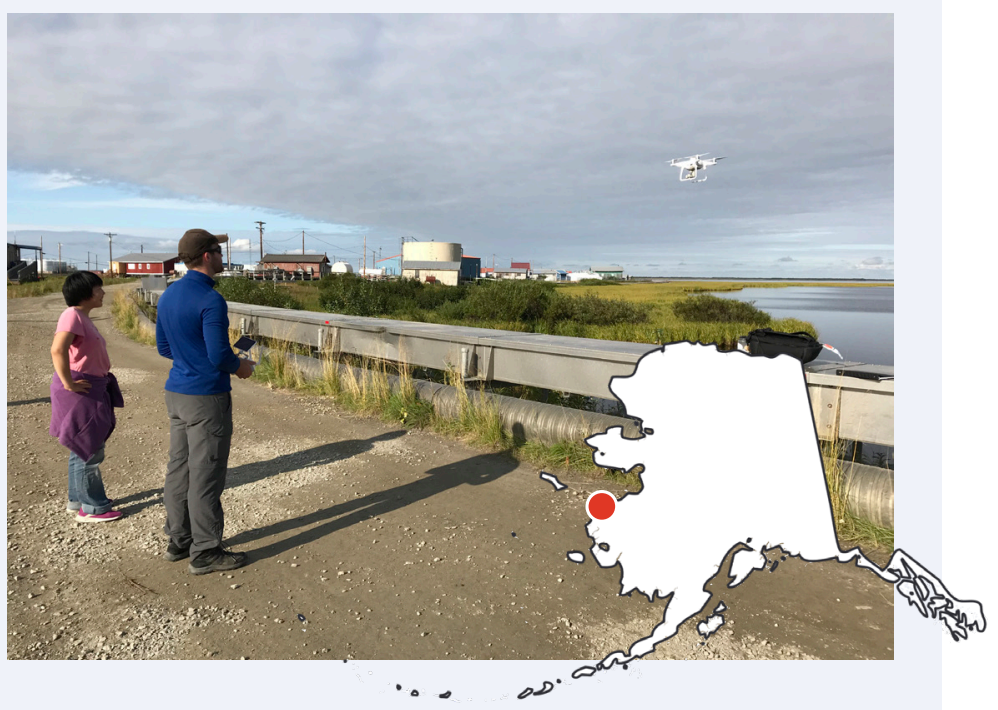

DGGS' Rich Buzard (right) uses a drone in Nunam lqua to assist in collecting data as part of an effort to provide tailored coastal mapping and monitoring to coastal communities. Photo: Jacquelyn Overbeck. throughout the process. Since 2009 DGGS has used remote sensing, ground surveying, and community outreach to overcome these baseline data gaps, and the Coastal Hazards Program is now developing tailored information for more than 40 tribal, city, and Native corporation entities. Information about our coastal flooding and erosion monitoring efforts at Alaska communities is publicly available on our website at dggs.alaska.gov/hazards/coastal/monitoring.html.

At the request of Alaska coastal communities, DGGS traveled to Golovin, Shaktoolik, Unalakleet, and Nome in August 2019 to measure erosion from a large storm. Post-storm measurements were used at Golovin community planning meetings and for a National Coastal Resilience Grant application by the Native Village of Shaktoolik. That federal grant application to the National Fish and Wildlife Foundation was successful, and the Native Village of Shaktoolik received $\$ 1$ million to repair a storm-damaged berm that protects the community.

In 2019 the Coastal Hazards Program also conducted field investigations in Kotzebue, Nunam lqua, Tununak, and Wainwright. DGGS helped install real-time continuous water level sensors in Kotzebue, Tununak, Nelson Lagoon, and Naknek, and collected tidal data via short-term water level observations in Naknek, Levelock, Kwigillingok, Kongiganak, Tuntutuliak, Napakiak, Napaskiak, and Gambell.

In addition to information resources requested by individual communities, DGGS has also been working to provide the most comprehensive and consistent datasets for flood and erosion hazards for all Alaska coastal communities. Efforts to develop these products were a major undertaking in 2019, and they are on track to be published in 2020. 


\section{EARTHQUAKES AND TSUNAMIS}

DGGS launched an immediate response to the November 2018 Anchorage earthquake, assisting in mapping efforts with the Division of Mining, Land and Water, the U.S. Geological Survey, and the Bureau of Land Management, among others, to successfully conduct a lidar survey flown in the aftermath of the earthquake. DGGS provided information to the national Geotechnical Extreme Events Reconnaissance (GEER) team, conducted a high-resolution aerial photography survey of highway corridors and damage sites at the direction of DOT\&PF, and is collaborating with state and federal colleagues to continue the discussion of how best to move forward in the face of future potentially damaging earthquakes.

DGGS continues to manage the DNR portion of the federally funded Tsunami Hazards Mitigation Program by increasing earthquake and tsunami hazard awareness across the state. In FY2019 we published inundation maps showing areas that could be affected by future potential tsunamis at Akhiok, Chiniak, Karluk, Larsen Bay, Old Harbor, Ouzinkie, Port Lions, Port Alexander, Craig, Ketchikan, False Pass, Perryville, Shemya, Anchor Point, Nanwalek, Port

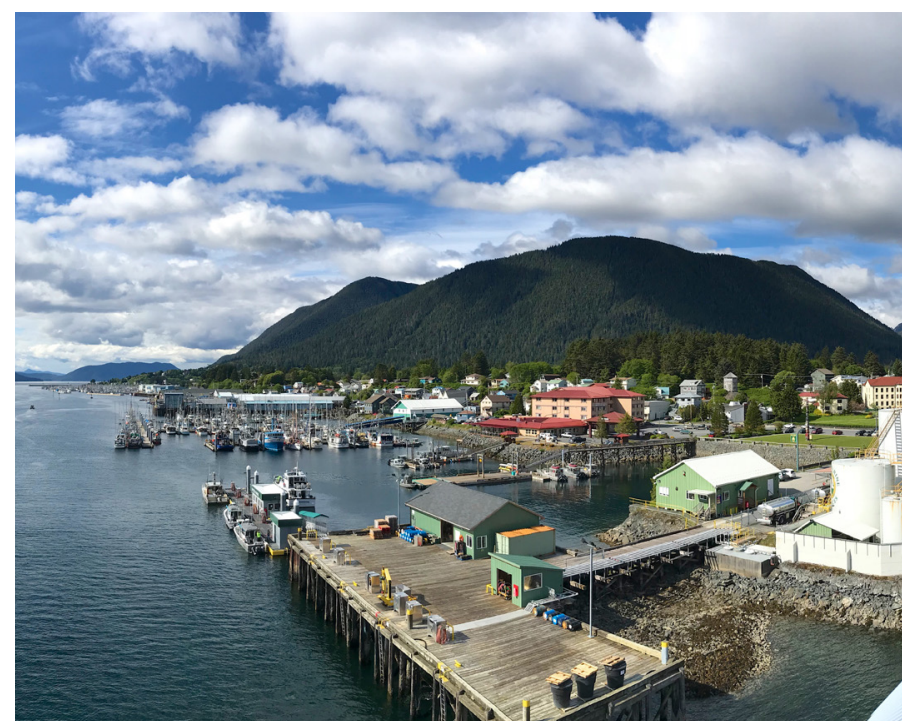

View looking north from O'Connell Bridge towards ANB Harbor in Sitka. DGGS scientists often travel to coastal Alaska communities to discuss earthquake and tsunami hazards research.

Photo: Barrett Salisbury.
Graham, Adak, and Atka. We also published updated tsunami inundation maps for Homer and Seldovia. Results of these investigations have been disseminated to local emergency planners. We constantly work with the Division of Homeland Security and Emergency Management (DHS\&EM) to communicate tsunami hazards to at-risk communities - both in person and through published reports.

\section{CLIMATE AND CRYOSPHERE}

The DGGS Climate and Cryosphere Hazards Program installed a new high-elevation weather station on Harbor Mountain near Sitka to acquire critical weather data needed to quantify thresholds for landslide initiation. This weather station is an essential component of a landslide early warning system (LEWS) for Sitka.

The DGGS Climate and Cryosphere Hazards Program initiated a statewide snow avalanche hazard assessment project to develop comprehensive avalanche hazard information designed to support public safety and the security of infrastructure and resources. Program manager Gabriel Wolken was awarded a research fellowship by the Swiss Federal Institute for Forest,

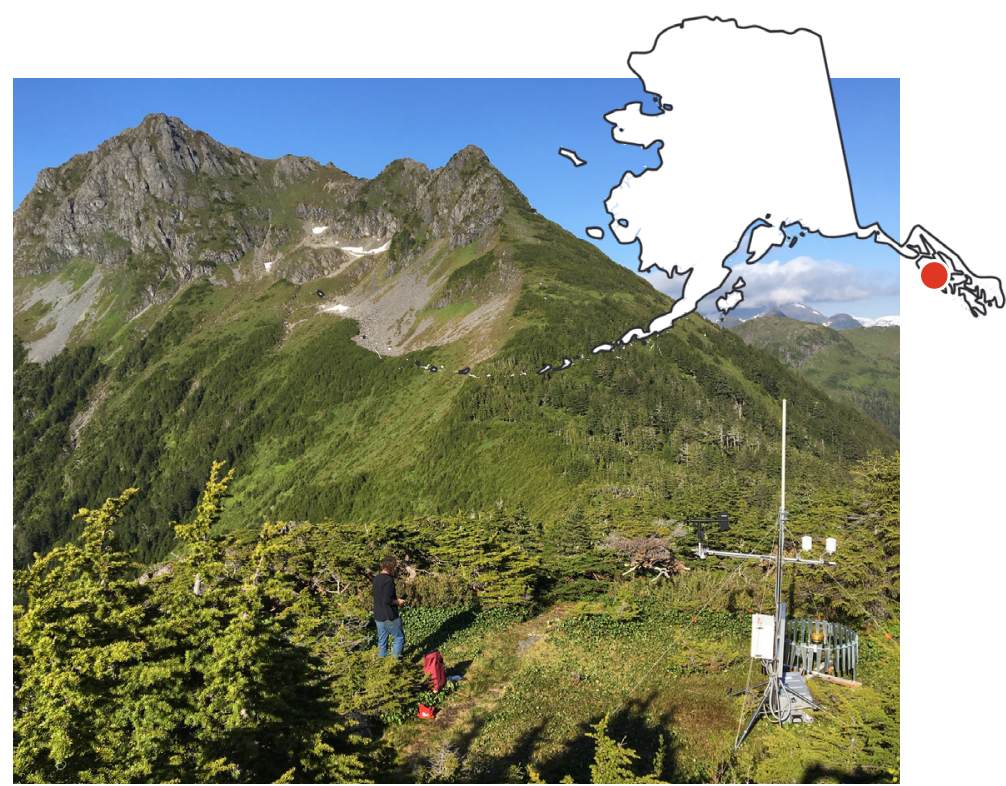

DGGS Climate and Cryosphere Hazards Program scientists installed a weather station on Harbor Mountain near Sitka in 2019. This weather station is part of a landslide early warning system for the city of Sitka. 


\section{North Slope Sand and Gravel Resource Assessment}

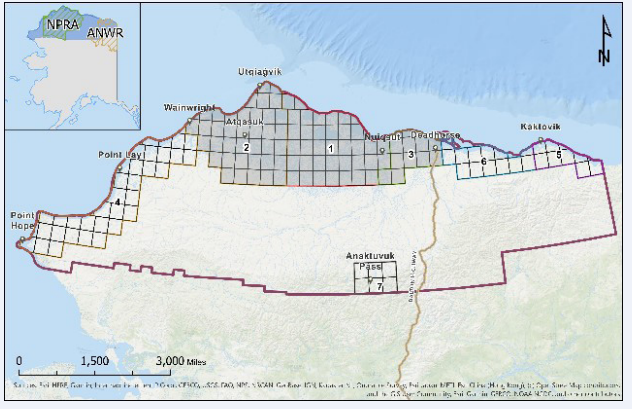

Area being evaluated for construction materials resources. Gray shading indicates terrain unit mapping completed in 2019.
In 2019, DGGS made great strides in assessing northern Alaska construction materials resources in support of the Arctic Strategic Transportation and Resources (ASTAR) project. This collaborative effort, initiated by the Department of Natural Resources in partnership with the North Slope Borough, plans to strengthen community infrastructure and facilitate access to arctic resources while enhancing the quality of life and economic opportunities for North Slope communities. Additional financial support by the Bureau of Land Management, for parallel resource assessment in the National Petroleum Reserve-Alaska (NPRA), allowed the division to leverage state funding to enhance the project's scope of work.

This DGGS project is identifying potential sources of construction materials (chiefly sand and gravel) for an approximately $38,000 \mathrm{mi}^{2}$ area of Alaska extending roughly from Point Hope to the Canada border, focusing on community-interest lands. In 2019 DGGS built upon and expanded prior work, with key project milestones that included

- Acquiring existing terrain unit mapping from ASRC Energy Services (AES Alaska) and contracting them to close data gaps and assess potential geologic hazards through the interpretation and analysis of remote sensing data

- Creating and populating a geodatabase with sand and gravel resource information from more than 30,000 seismic shot-hole sediment samples archived at the Geologic Materials Center in Anchorage and a second geodatabase with sand and gravel resource information from available drill-hole data

- Conducting fieldwork in northeastern NPRA and near the Canning/Staines rivers adjacent to the Arctic National Wildlife Refuge (ANWR), to determine the character and
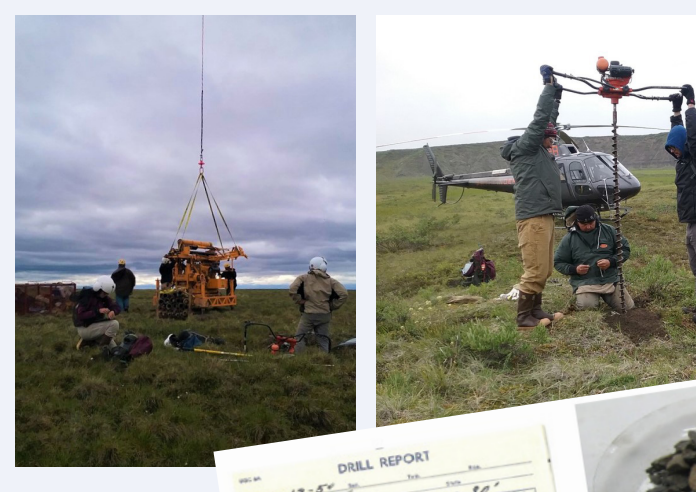
$\frac{1}{3-\frac{6}{5}}$

Top left. DOTEPF crew assembling helicopterslung drill rig at potential gravel site during 2019 fieldwork.

Top right. Fieldwork using a power auger to gather samples and data about material distribution and characteristics. Bottom. Example of legacy drillhole field data cards and sediment samples archived at the GMC that are being used to create a geodatabase of subsurface information. distribution of potential construction materials and validate the terrain unit mapping. The twenty-day NPRA field campaign included partnering with the Alaska Department of Transportation and Public Facilities (DOTEPF) to drill nine gravel exploration boreholes using a helicopterslung drill rig

The ASTAR sand and gravel resource assessment will benefit Alaska by providing a comprehensive dataset of surface and subsurface information about construction materials resources over a large area of the North Slope. The goal of the work is to distribute consistent geologic mapping at a more detailed scale than is currently available and distribute new information about potential geologic hazards that could impact development. DGGS hopes that these datasets will help interested parties make prudent land-use decisions and promote successful infrastructure projects. 
Snow, and Landscape Research to develop the Alaska large-scale snow avalanche hazard mapping project with avalanche experts in Switzerland. This fellowship initiated an important long-term collaboration with the Swiss Institute for Snow and Avalanche Research, which is leading to important advances in Alaska avalanche research, helping the State of Alaska develop sciencebased adaptation and response strategies to avalanches, and improving community resilience.

\section{LIDAR}

In 2019 DGGS successfully completed more than a dozen airborne lidar surveys, covering over $800 \mathrm{mi}^{2}$, to collect high-resolution elevation data needed to assess geologic hazards and support resource assessments throughout the state. Our Climate and Cryosphere Hazards Program is using these data to map snow distribution in complex mountain terrain across Alaska in support of improved hydrological and avalanche runout modeling. Landslide hazard assessments at Homer, Sitka, and the Haines and Dalton highways require these data to effectively and efficiently evaluate the potential for slope failures. Multiple projects in northern Alaska are utilizing data collected by our novel backpackborne platform to perform detailed analysis of permafrost characteristics. Lidar collected at Kotlik will be used to map previous coastal storm extents at the community, and determine the extent of permafrost-affected ground. Our largest lidar campaign to-date covers approximately $500 \mathrm{mi}^{2}$ in support of the ASTAR sand and gravel resource analysis in high-priority areas of the NPRA.

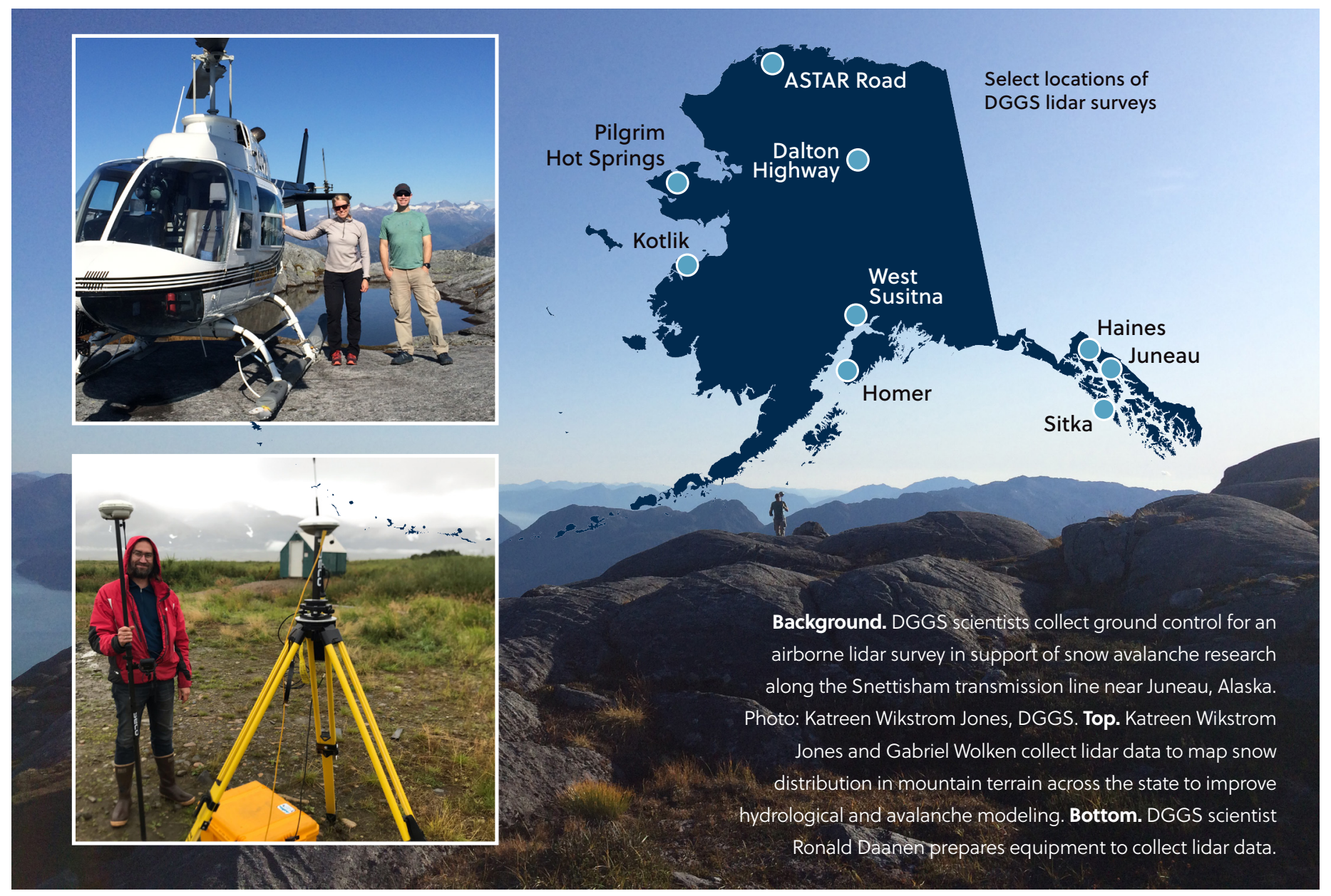




\section{Avalanche Hazard Mapping for Alaska's Safe and Sustainable Future}
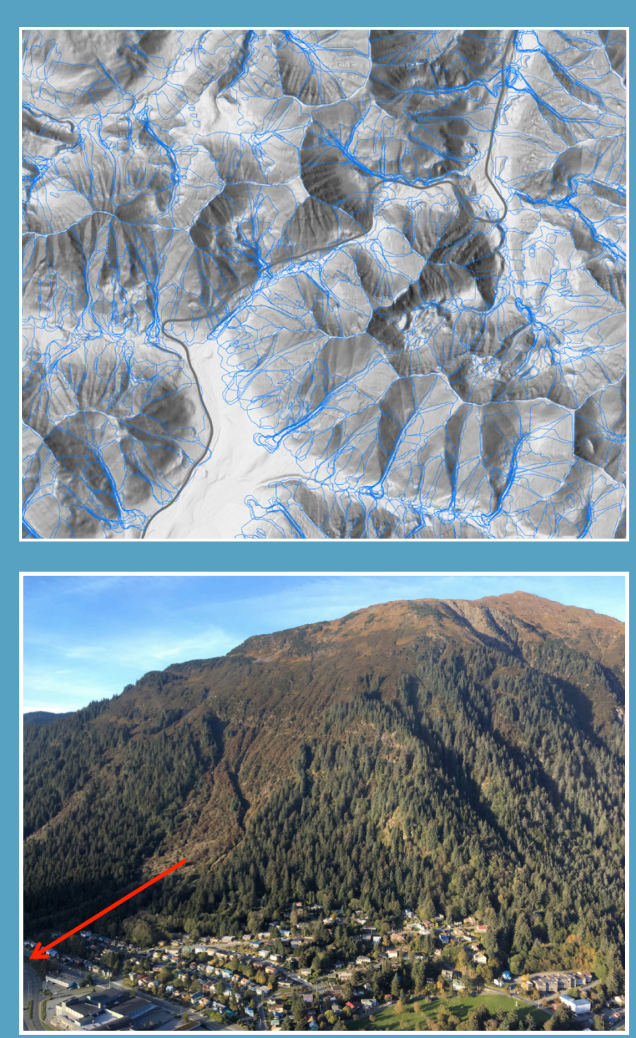

Left. Preliminary avalanche hazard

indication map for Atigun Pass in the Brooks Range. Right. The Behrends Ave. avalanche path in downtown Juneau. The red arrow indicates the direction of runout simulated for large avalanches generated from this path, which threatens homes, businesses, a critical transportation corridor, and a small boat harbor. Juneau has the highest urban avalanche danger of all U.S. municipalities.

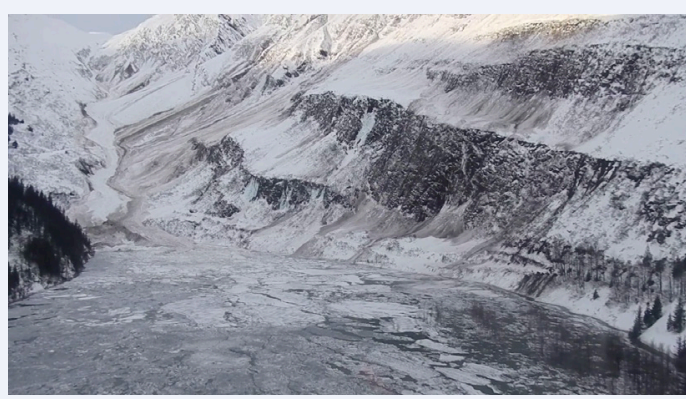

Snow avalanches threaten public safety, infrastructure, and commerce in Alaska, and climate change is expected to increase our vulnerability as avalanches become more frequent and difficult to predict. In the past 20 years, snow avalanches have killed 85 people in Alaska-the most common cause of death from a natural hazard in Alaska. However, despite the risk that avalanches pose to the state, Alaska has lacked a comprehensive understanding of where avalanches can occur.

Alaska's size and complex terrain make avalanche hazard assessments particularly challenging. Previous studies have estimated that about thirty percent of Alaska's total land area is at risk from snow avalanches. As the climate continues to change, it becomes increasingly important for us to understand how and where snow avalanche hazards will change, which is critical information to ensure responsible, safe, and sustainable development in Alaska. With infrastructure development planned in many parts of Alaska, and subsistence and outdoor recreation a way of life for most residents, the state has much to gain from improved understanding of snow avalanche hazards. To address this information gap, Gabriel Wolken, manager of the Climate and Cryosphere Hazards Program (CCHP) at DGGS, and research professor at the University of Alaska Fairbanks, is leading a statewide effort to map avalanche distribution in Alaska.

Wolken was awarded an international research fellowship in Davos, Switzerland, to study and map Alaska's snow avalanche hazards. The six-month fellowship during winter 2018-2019 was designed to promote collaboration between visiting senior-level researchers and scientists at the Swiss Institute for Snow and Avalanche Research (SLF).

Wolken worked with some of the world's leading snow and avalanche scientists to develop avalanche hazard mapping techniques that would accommodate Alaska's multiple climate zones, complex topography, and lack of climate and snow data. Wolken and CCHP Natural Resources Specialist Katreen Wikstrom Jones are now continuing work with Swiss avalanche scientists to adapt avalanche modeling and mapping methods to local training areas in different climate zones in Alaska in order to expand the techniques to a statewide assessment of avalanche hazards.

A rain-on-snow event in January 2014 caused a large avalanche that dammed the Lowe River and blocked the Richardson Highway near Valdez, AK for two weeks. The event, referred to as a "Damalanche" resulted from an extreme precipitation event that delivered tremendous amounts of snow and rain to the eastern Chugach Mountains. 


\section{VOLCANOLOGY}

The Volcanology program of DGGS is part of the Alaska Volcano Observatory (AVO), an interagency consortium that mitigates hazards from Alaska volcanoes. AVO was formed by Memorandum of Understanding in 1988. Its partners are DGGS, the USGS, and the University of Alaska Fairbanks Geophysical Institute (UAF/GI). The Director of DGGS established Volcanology as a separate section in early 2007. Funds for DGGS participation in AVO come from cooperative agreements with the USGS through the USGS Volcano Hazards Program.

AVO studies volcanoes to increase understanding of general volcanology and of hazards at specific volcanoes; monitors volcanoes using seismology, geodesy, satellite remote sensing, field studies, and local observers; and provides timely and accurate warning of increasing unrest and eruptions to emergency management agencies, other government entities, the private sector, and the public. The majority of Alaska's
54 historically active volcanoes are remote from human settlements, but all underlie the heavily traveled North Pacific passenger and cargo air routes between North America and Asia; thus, the aviation sector is an important recipient of AVO monitoring reports.

Volcanology Section staff continue to play a lead role in AVO communication and operations by maintaining a robust database of Alaska volcanoes, with several database modules available to the public through the DGGS-managed Alaska Volcano Observatory website at avo.alaska.edu. Users can find the latest information on volcanic unrest and eruption; search, view, and download thousands of well-captioned images of Alaska volcanoes; and learn about past eruptive history and current hazards.

The most significant publication of the Geologic Database of Information on Volcanoes in Alaska (GeoDIVA) was the release of The Alaska Geochemical Database, v. 2. This database was originally released as

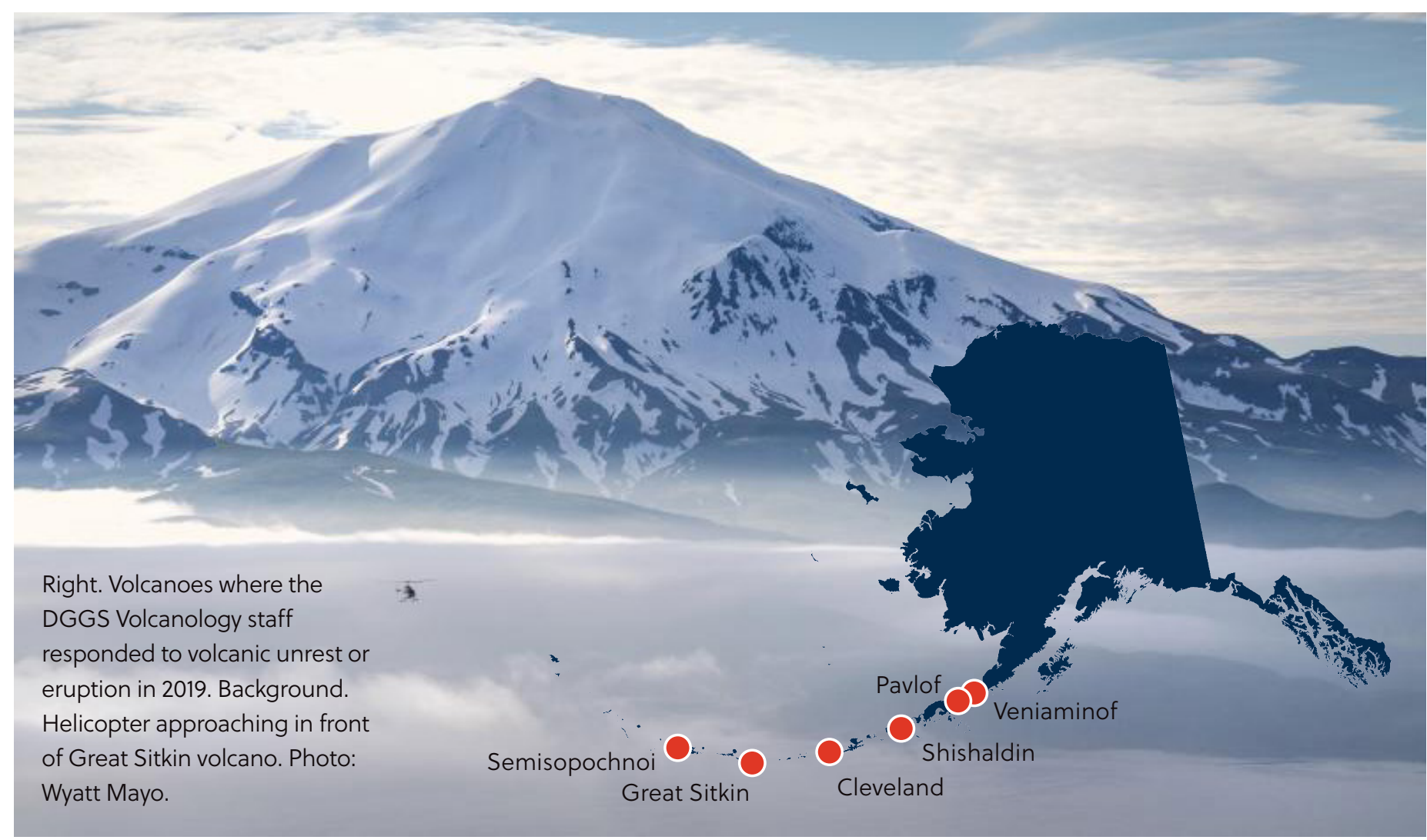




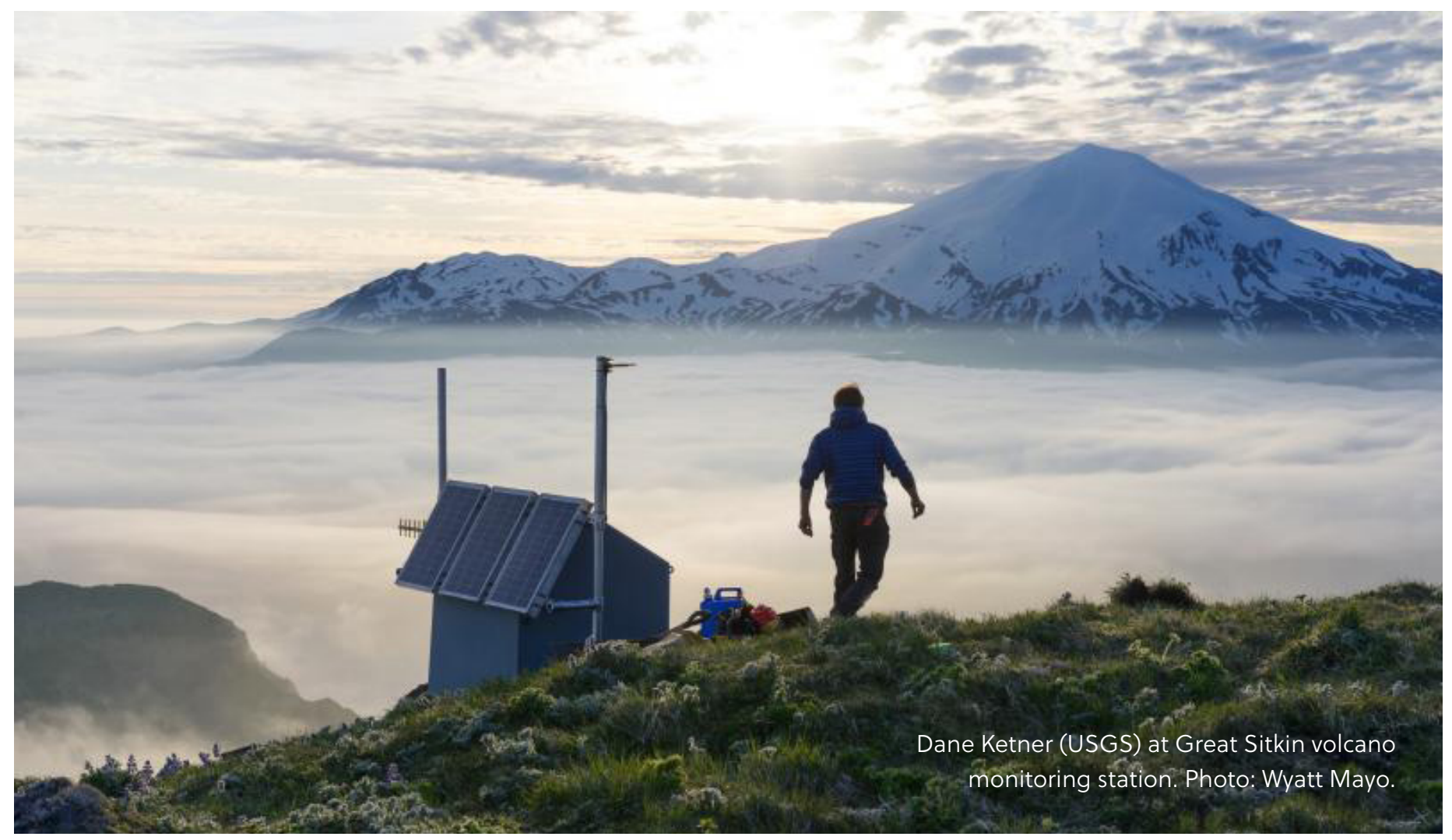

a searchable online database of whole-rock chemistry. Over the last three years, tephra glass data have been added and a new search interface constructed to allow users to query both whole rock and glass data, and to calculate similarity coefficients of ashfall-glass chemistry. We expect this tool to be used not only by scientists conducting research in ashfall hazards but also by those using tephra to reconstruct climate history or to date important archaeological sites. Currently, the geochemistry database contains $-9,700$ whole-rock analyses and -3,000 tephra analyses from Alaska and the Yukon Territory, Canada.

\section{FIELD WORK AND ERUPTION RESPONSE}

DGGS-AVO staff managed helicopter procurement and fuel logistics that supported 160 days of helicopter-based fieldwork in remote Alaska from Cook Inlet to the western Aleutians. Field operations included contracting 84 days of the marine research vessel $\mathrm{R} / \mathrm{V}$ Steadfast. Operational costs for this endeavor come from a new $\$ 4.7 \mathrm{M}$ USGS/DGGS cooperative agreement grant to develop a robust system of monitoring instruments to collect digital data that will help provide advanced warning of volcanic activity.

DGGS field technicians, along with USGS colleagues, completed extensive upgrades to volcano monitoring equipment. Instrumentation was upgraded at 13 volcanoes: Akutan, Augustine, Dutton, Gareloi, Great Sitkin, Iliamna, Kanaga, Katmai, Korovin, Makushin, Okmok, Tanaga, and Westdahl. The new ground-based instrumentation includes seismometers, infrasound sensors, and web cameras; and significantly improves AVO's ability to detect unrest, forecast eruptive activity, and issue timely alerts of volcano hazards.

DGGS Volcanology Section staff responded to volcanic unrest or eruption at Cleveland, Semisopochnoi, Shishaldin, Veniaminof, Pavlof, and Great Sitkin volcanoes. Response activities included issuing volcanic eruption alerts in collaboration with USGS and UAF colleagues, 24/7 seismic and satellite monitoring, detailed record-keeping of eruptions and impacts, and maintaining current information on the public website, and Facebook and Twitter feeds. 


\section{Extensive Upgrades to Voleano Monitoring Equipment Provides Advanced Warning of Volcannic Activity}

In 2019, DGGS received a three-year cooperative agreement grant from the USGS Volcano Hazards Program to replace old analog volcano monitoring equipment with new digitally telemetered instruments. This upgrade will significantly improve our ability to provide advanced warning of volcanic activity, allowing AVO to warn the public of impending volcanic hazards and dangerous drifting ash clouds. The digital conversion improves data quality because digital data telemetry is less susceptible to external noise sources than analog telemetry, which translates to more accurate and timely forecasts of volcanic eruptions. In addition, the analog-to-digital telemetry conversion brings AVO volcano monitoring instruments in compliance with National Telecommunications and Information Administration (NTIA) radio spectrum guidelines.

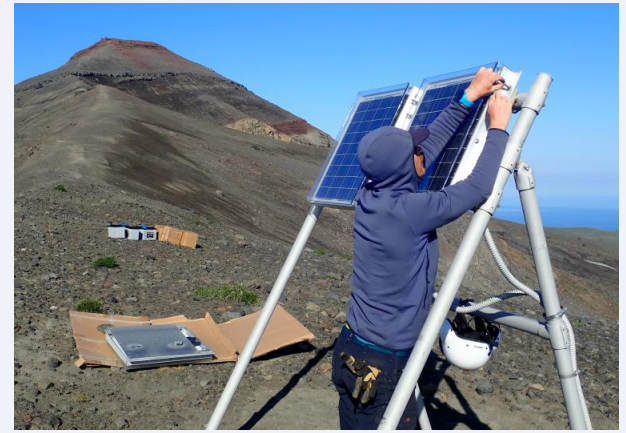

DGGS field technician, Malcolm Herstand, installs new solar panels at a critical repeater station on Okmok volcano. Photo: Max Kaufman, UAF.

\section{Pre-Field Preparations}

Intensive field preparations at DGGS included hiring four new personnel (two field technicians, one logistics coordinator, and one administrative assistant); securing contracts for a marine research vessel and helicopter; purchasing and deploying remote fuel stashes; creating detailed personnel and equipment plans for each volcanic center; coordinating staff with our USGS and UAF partners; purchasing, preparing, and shipping field equipment; and ensuring all staff had necessary field safety gear and proper training.

\section{Operational Statistics:}

- In cooperation with our USGS and UAF partners, AVO deployed over 50 individuals to the field to help with the digital upgrades

- On average, there were 12 field-staff working each day from June 1 through August 31

- 84 days of marine research vessel charter

- Over 100 helicopter days were flown

- Nearly 30 tons of equipment and supplies were shipped

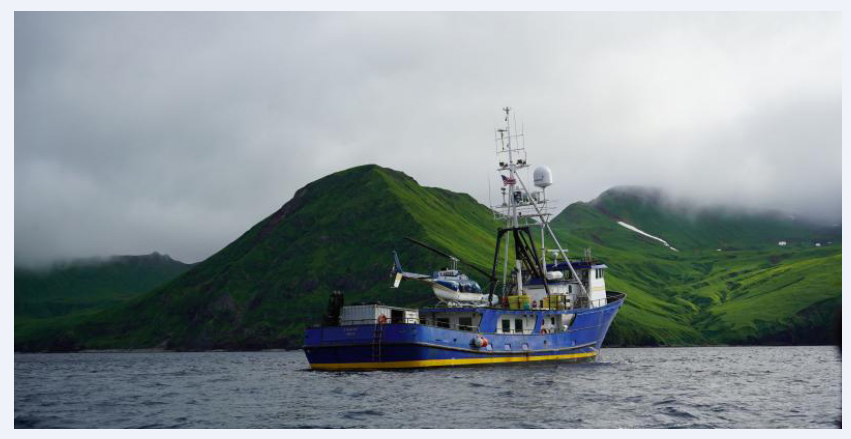

\section{Major Accomplishments:}

- 37 monitoring stations were upgraded from analog to digital

- Five complete seismic networks were upgraded from analog to digital at Korovin, Great Sitkin, Kanaga, Tanaga, and Gareloi

- Ten new infrasound channels are now on-line at Great Sitkin, Kanaga, Gareloi, Tanaga, Shishaldin, Pavlof, Augustine, Spurr, Redoubt, and Makushin

- Five new web cameras were installed at Tanaga, Gareloi, Kanaga, Great Sitkin, and Shishaldin

- Previously inoperable networks at Dutton and Wrangell received upgrades and have been moved from "unmonitored" to "monitored" status

The marine research vessel Steadfast (shown here offshore of Tanaga Island) was the base of helicopter operations for Aleutian analog to digital volcano monitoring instrument upgrades. Photo: Taryn Lopez, UAF. 


\section{GEOLOGIC INFORMATION CENTER}

Basic geologic information about Alaska's resources helps to inform land-management decisions and encourage investment, exploration, and development of the state's resources, resulting in billions of dollars of impact to Alaska's economy. Availability of information specific to the state's volcanoes, earthquakes, landslides, tsunamis, coastal erosion, climate change, and other natural hazards helps mitigate these hazards, helping to save lives and reduce damage to property and critical infrastructure. The staff within the Geologic Information Center (GIC) design, edit, publish, and deliver divisiongenerated geologic information as authoritative, peerreviewed maps, manuscripts, geospatial datasets, and easy-to-use online applications.

DGGS now archives and maintains more than 723 terabytes (TB, $1 \mathrm{~TB}=1,000$ gigabytes) of digital and map-based geological, geophysical, and geochemical data in a division-wide database that plays an integral part in distributing information through the DGGS website (fig. 1). In 2017, the division celebrated the release of its 5,000th publication: "Potential maximum permanent flooding maps for the communities of Chignik and Chignik Lagoon, Alaska." As a result of this publication benchmark, DGGS has released an average

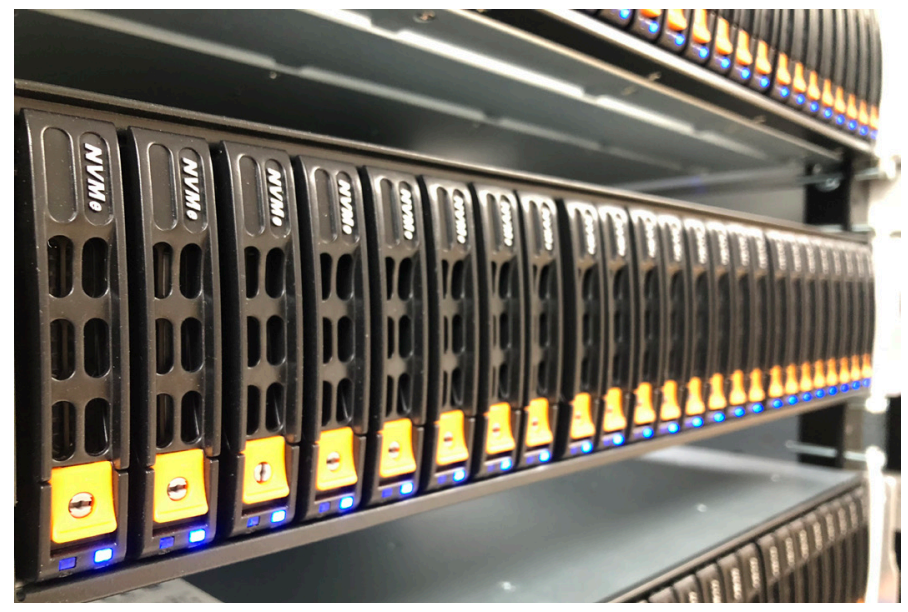

DGGS implements a "hot/warm/cold" disk access and archive solution, with "hot" data being accessed more frequently on solid state drives and "cold" data being compressed and archived on slow, older, mechanical drives. of one publication every four business days since Alaska achieved statehood in 1959.

DGGS publication, Geographic Information Systems (GIS), cartographic, and programming services helped foster $1.15 \mathrm{M}$ downloads of digital datasets and reports, totaling more than 50 terabytes (including 16.7 TB from elevation data) of information in FY2019 with more data being provided through interactive maps, online databases, and GIS services. The GIC continued to add a multitude of elevation data to our public online applications from lidar, IfSAR, and Structure from Motion (SfM) sources (elevation.alaska.gov). Since digital delivery has become a major, cost-effective method of

\section{Project Highlight}

\section{Alaska DGGS Geoportal}

The Geologic Information Center also released many digital geologic datasets through its new, online GeoPortal. The Alaska DGGS GeoPortal allows users to share, discover, and access geologic data, maps, and interactive applications and is part of the State of Alaska Spatial Data Infrastructure managed by the Alaska Geospatial Council, which includes the Alaska DNR Open Data Site.

\section{geoportal.dggs.dnr.alaska.gov/portal}

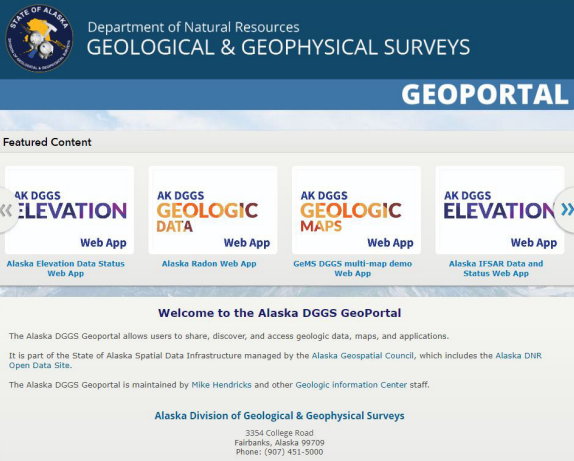


distributing information only 78 hardcopy publications were sold in FY2019.

DGGS personnel responded to more than 3,100 geologic information requests and DGGS ended the year with more than 4,221 followers on Twitter, 750 subscribers to the division's RSS feed, and nearly 900 followers on the DGGS Facebook page. The section helped publish 17 Information Circular reports (dggs.alaska. gov/pubs/series/dggs/information-circular) on topical geologic concepts and themes, including earthquakes, radon, asbestos, coastal erosion, and volcanoes. These concise, two-page summaries help inform the public and decision-makers about Alaska's natural resources, the impacts of natural hazards, and the dedicated work of DGGS geologists and staff.

The GIC implemented a version of a multi-user GeMS Geodatabase for geologic map production, with many geologic map projects now using a GeMS multi-user PostgreSQL Enterprise Geodatabase. The section performed quality control for and loaded all of DGGS's 2018 geochemical analyses into the database, giving users access to the full dataset of Alaska-related analyses, and assisted geophysicists in archiving and

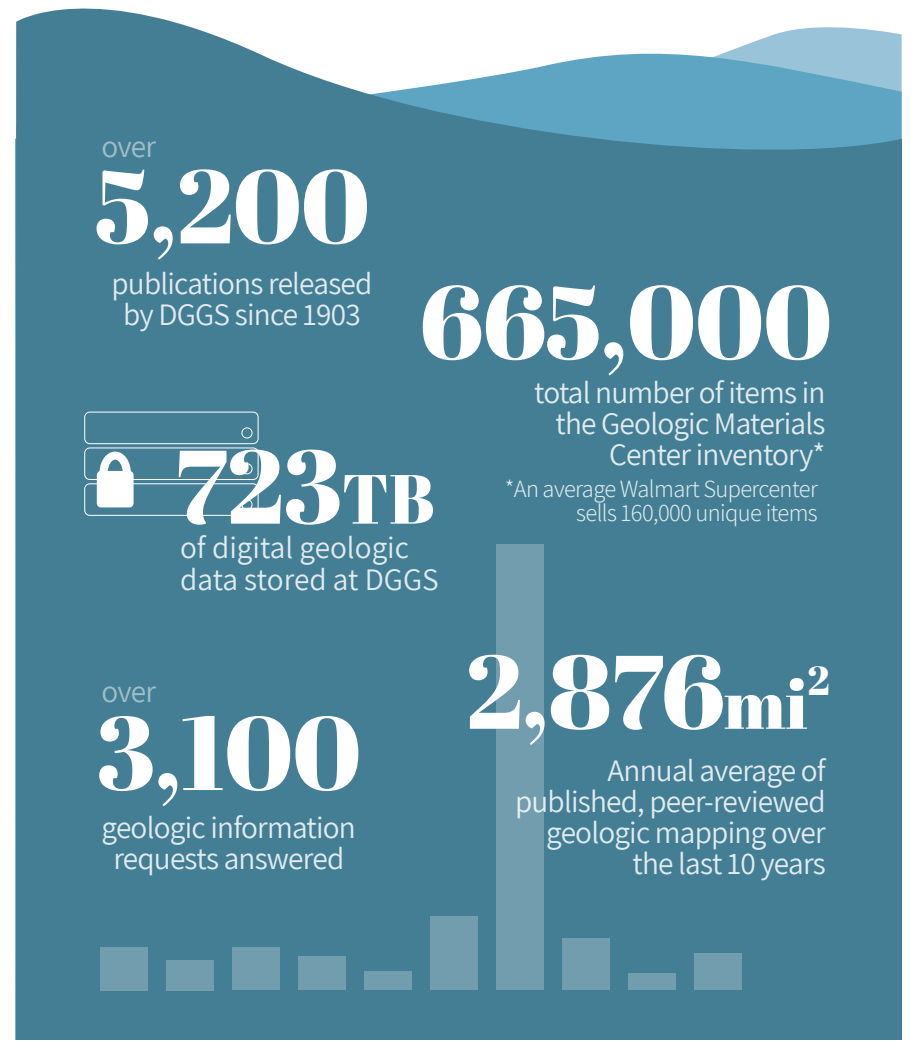

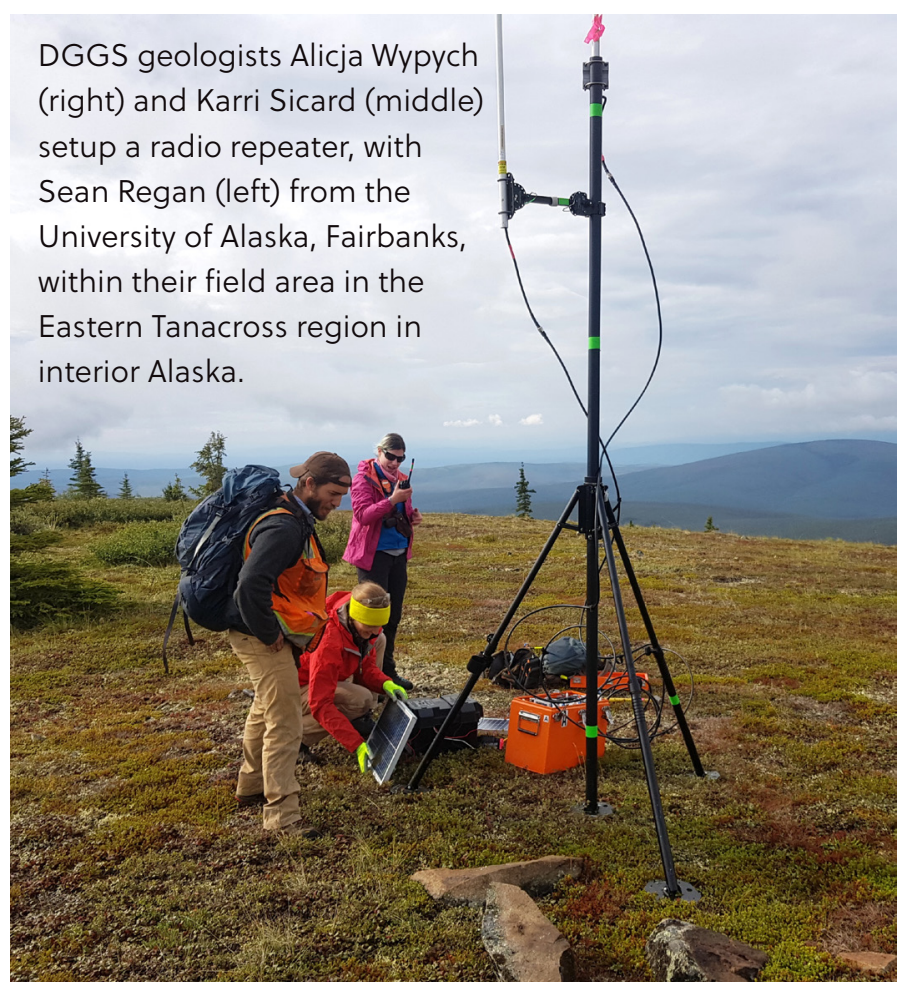

preparing 43 historical airborne geophysical surveys for online publication. Of these datasets, 19 were digitally re-released online, and DGGS anticipates all "modern" airborne geophysical surveys will be made available online in FY2020.

The GIC led monthly collaborative meetings with other state and national geologic surveys to design and implement an enterprise geologic database, shaped model parameters, and provided input on details of the project. In addition we presented progress on this design effort at several national-level meetings. As a result, the USGS and National Cooperative Geologic Mapping Program is interested in using the DGGS model for Earth MRI and national digital map data.

Lastly, the section provided field safety and communication equipment to support late summer 2018 and early summer 2019 fieldwork. The overall number of DGGS field staff for FY19 was roughly double that of recent prior years. Equipment and procedural upgrades included field testing GPS trackers for remote communication and emergency location, as well as ongoing work to identify and disseminate guidelines and recommendations for field safety best practices. 


\section{ALASKA GEOLOGIC MATERIALS CENTER}

The Alaska Geologic Materials Center (GMC), operated by DGGS, archives 75 years' worth of geologic data and more than 665,000 energy, mineral, and geologic samples with an estimated replacement value exceeding $\$ 35$ billion. The facility provides a wide range of users (industry, government, academia, and public) access to samples for identifying new resource prospects and increasing our geologic knowledge of the state.

In the past, this has been done under a very limited budget in a thoroughly inadequate and outdated facility with limited availability of samples due to cold storage in winter. The new Anchorage repository opened July 1, 2015 and has completed its fourth fiscal year. Senate bill SB170, signed by Governor Walker in June 2016, allowed DGGS to "charge and collect fees for facilities, equipment, products, and services." Fee collection began in Fall 2018 and the GMC is now a revenuegenerating facility for the state. For example, tax credit distributions of seismic datasets have generated more than $\$ 1 M$ in fees.

There were 1,475 visits to the facility in FY2019 (the average annual number of visitors, prior to

The GMC in Anchorage stores 75+ years' worth of geologic data and more than 665,000 geologic samples. opening the new Anchorage facility, was 400) and the fiscal year saw several major successes for clients of the GMC. Proximity and higher visibility to the much larger population center of Anchorage has continued to increase both institutional and public visitors to the facility. Visits from the energy industry

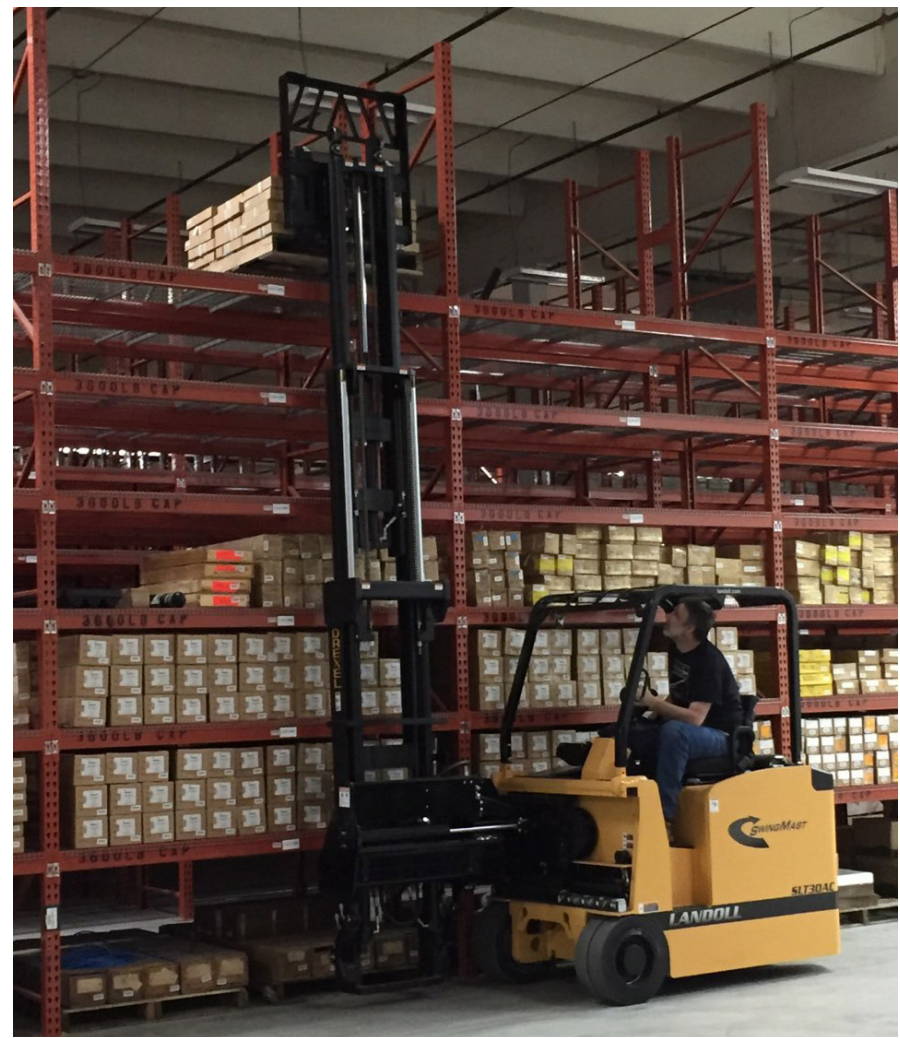

\section{GMC Visitors}

The GMC lead 65 tours representing more than 465 visitors from more than 15 school and public groups.

\section{There were 1,475 visits to the facility} in FY2019 (the average annual number of visitors, prior to opening the new Anchorage facility, was 400) and the fiscal year saw several major successes for clients of the GMC.

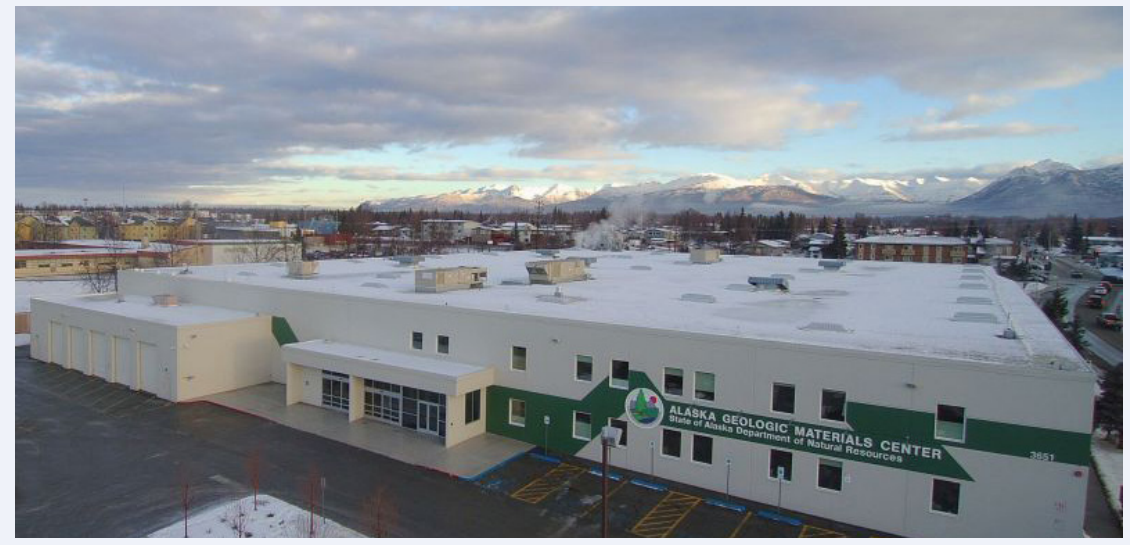


more than doubled this year as interest in the North Slope Nanushuk play continued to increase. Markets for metals remained depressed this year and mining industry visits stayed low.

Geologists from independent and major energy companies visited the GMC to sample and examine hundreds of feet of drill core and cuttings. As production declines within the mature Prudhoe Bay oil field, it is essential to diversify the oil industry in Alaska. The GMC hosted visits by major and independent oil companies and government researchers operating in both the North Slope and Cook Inlet regions, including ConocoPhillips, Oil Search Alaska, Hillcorp, Glacier Oil \& Gas, Armstrong, Repsol, Alaska Gasline Development Corporation, U.S. Geological Survey, U.S. Department of Energy, and the U.S. Bureau of Ocean Energy Management.

Professional development and outreach at the GMC were highlighted through nationwide participation in the GMC Alaska Oil and Gas Association Technical
Breakout Session, which assessed non-destructive analysis technologies performed on North Slope energy samples and conducted core workshops for Oil Search Alaska and the U.S. Bureau of Ocean Energy. In FY2019, the GMC also lead a total of 65 tours, including those for education, representing more than 465 visitors from more than 15 school and public groups.

During FY2016 there was a drastic shift in tracking client access to the GMC inventory. The former paper file inventory system was replaced by a more modern browser-based inventory search interface in January 2016 (maps.dggs.alaska.gov/ gmc). The new database-driven search engine allows users to quickly and easily view real-time details of the more than 665,000 sample items in the GMC's inventory before visiting the facility. This innovative and complex database and online search engine was developed in-house by DGGS staff and continues to serve user needs (more than 14,000 user sessions in FY2019) and receive positive feedback from industry.

\section{Browse Samples Online!}

The GMC's browser-based inventory search engine allows users to quickly and easily view real-time details of the more than 665,000 sample items in the GMC's inventory. This innovative and complex database and online search engine was developed in-house by DGGS staff in FY2016 and continues to serve users' needs and receive positive feedback from industry. There were more than 14,000 user sessions in FY2019!

maps.dggs.alaska.gov/gmc

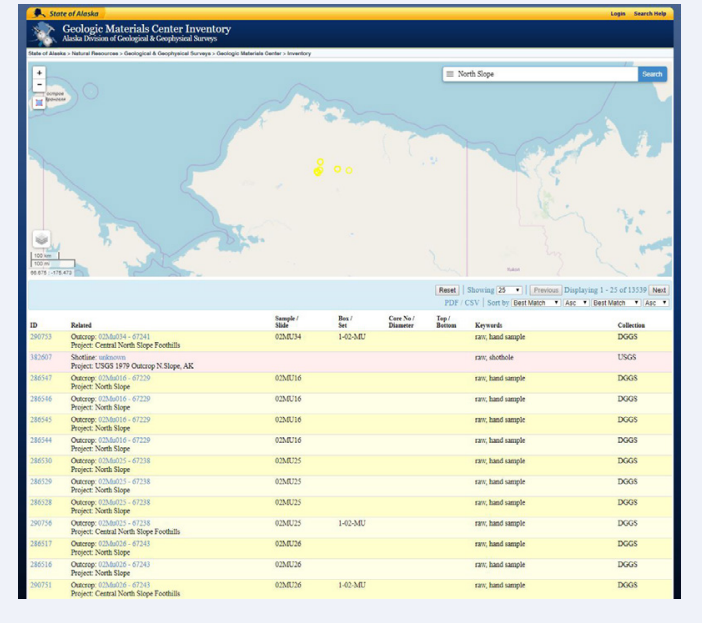




\section{Welcome!}

\section{ORALEE NUDSON}

Oralee recently joined DGGS after three and a half years as a Systems Administrator for the Geographic Information Network of Alaska (GINA) at the University of Alaska, Fairbanks (UAF). Oralee has 13 combined years of experience as a Systems Administrator, Science Analyst, and a UAF Information Technology (IT) User Consultant. With both Bachelor's and Master's Degrees in Computer Science and a B.S. in Psychology from Boise State University, Oralee really knows how computers work, think, and behave. She is also in the process of receiving her Network and Cybersecurity IT Specialist certificate at UAF.

\section{Farewell!}

\section{JULIA GARRITY}

Julia joined DGGS in December 2018, as an Administrative Assistant. She came in ready to apply her seven year DNR finance background to her role here with us. She ushered us through our procurement needs of 2019, which included an active field season and many new purchasing contracts and funding sources. Julia wrapped up her year with DGGS in December 2019, moving on to focus on her family. Having been born and raised in Fairbanks, Alaska, she and her family plan to remain in this area. She looks forward to keeping in touch with the kind, brilliant people that are DGGS.
When she's not overseeing the life-cycle management of hundreds of virtualized servers and maintaining nearly one petabyte of data in large volume and distributed fault tolerance storage systems, Oralee enjoys Alaskan living, summer trail running, yoga, bookmaking, and metalsmithing.

After a nine and half month search and several failed recruitments for her position, we are extremely pleased to have Oralee join us and lead the development and maintenance of the server and IT infrastructure for the division. It seems that good things do come to those who wait.

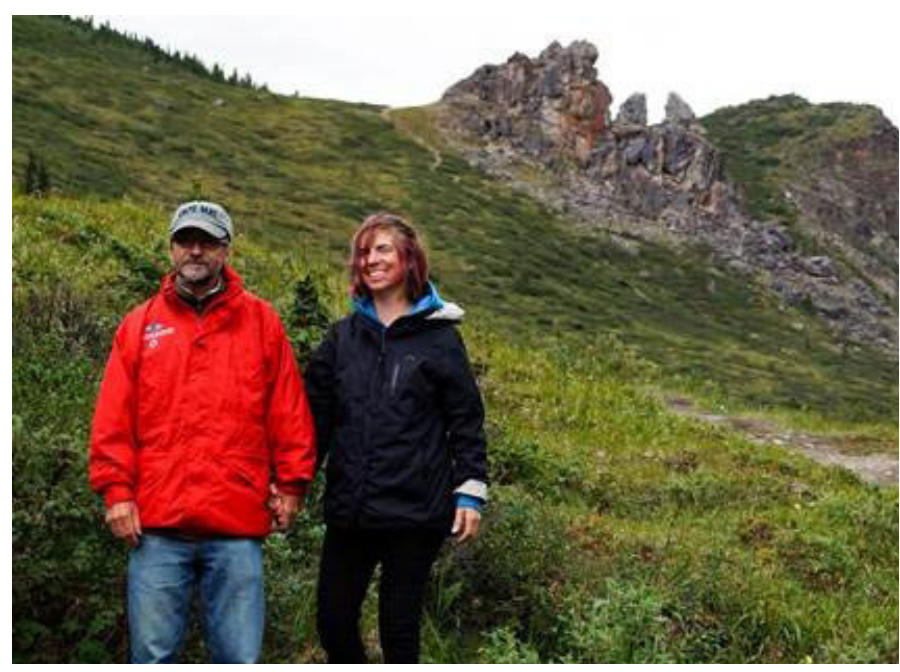

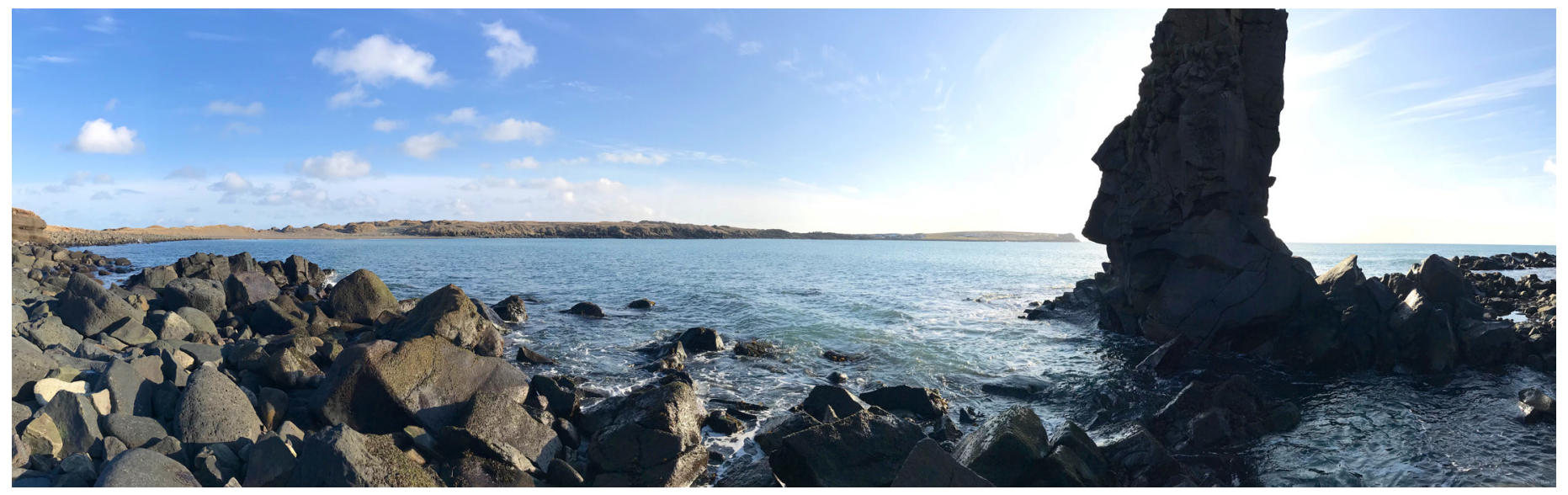

View looking south across the Gorbotch Rookery on St. Paul Island. Photo: Barrett Salisbury, DGGS. 


\section{Farewell (Again)!}

\section{Gina Graham}

Gina originally joined DGGS in 1992 as a Geological Assistant II to help with a major multi-year project to evaluate the resource potential of lands considered for selection as part of Alaska's statehood endowment, and later became GIS coordinator for all of our geologic mapping projects during a time when Geographic Information Systems technology was still in its infancy at DGGS. In 1997 she transitioned to a Microcomputer/Network Specialist I position, steering the DGGS GIS-IT team in creating and maintaining a stable, upgradeable, manageable network environment. She left us in December 2002 to become an IT manager with Alyeska Pipeline Service Company. Her notable IT skills aside, Gina's educational background is in geophysics and seismology, and we were excited to welcome her back in 2012 as a longterm nonpermanent Geologist III in support of the DGGS Geophysics Program.

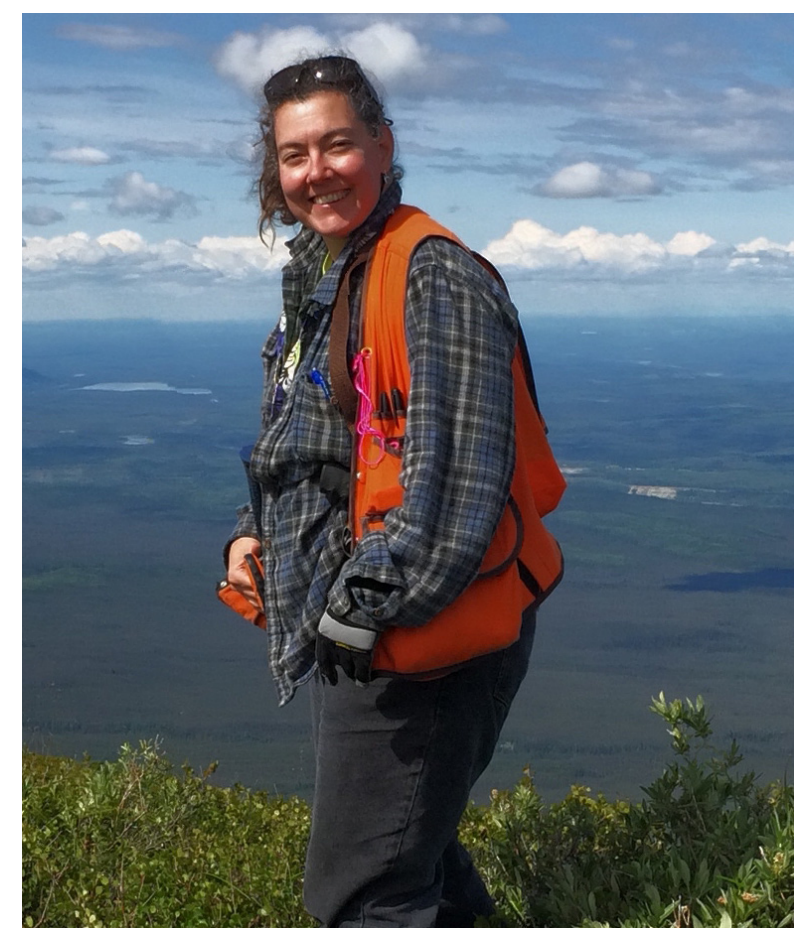

During this second incarnation at DGGS, Gina played a critical role in the online publication and archiving of approximately 60 airborne geophysical surveys collected by DGGS over the last two decades. She gathered and cataloged all physical media that contained data deliverables from the geophysical contractors resulting in negligible data loss. She collaboratively determined the data structure, naming conventions, and publication process for all DGGS potential field geophysical data creating an efficient, systematic method of archiving and publishing the data.

Gina performed her first data reviews in 2014, which led to the successful archival and online publication of the Iron Creek survey-the first "historical” survey under the new system. In 2015 Gina archived and published online the Petersville survey, proving the new system was transferable and repeatable for more-modern datasets. Over the years, Gina prepared multiple surveys for publication and her attention to detail made her the group's principal reviewer of surveys compiled by other geophysical staff members. Gina is a contributing author to the DGGS Geophysical Data Management Manual, has maintained the data layers underlying the Airborne GeophysWeb interactive web map of geophysical surveys for Alaska, and maintained the database of key metrics of all modern airborne geophysical surveys, providing us with this or that statistic at a moment's notice.

Gina is moving on because her hard work has resulted in the successful completion of the prodigious task she was hired to do. This will hopefully free up more time for her many outside pursuits, including sustainable gardening and playing with her dogs at her and her husband's off-the-grid home in the hills north of Fairbanks. We will miss her sense of humor, positive attitude, and careful stewardship of millions of dollars' worth of geophysical data. Happy gardening, Gina! 


\section{RELATIONSHIPS WITH OTHER AGENCIES}

DGGS develops its strategic programs and project schedules through consultation with the many users of geologic information: state and federal agencies, the Alaska Legislature, the congressional delegation, professionals in the private sector, academia, and individual Alaskans. Their input to DGGS programs comes through the Alaska Geologic Mapping Advisory Board, liaison activities of the Director, and personal contact between DGGS staff and the groups listed above.

\section{State Agencies}

DGGS provides other Department of Natural Resources (DNR) and state agencies with routine analyses and reviews of various geologic issues such as geologic hazards; evaluations of pending oil and gas lease tracts; area plans; competitive coal leases; geologic assessments of land trades, sales, selections, or relinquishments; oil and gas and mineral potential; and construction materials availability.

\section{Each year DGGS works closely with:}

- DNR Division of Oil \& Gas (DOG) on issues related to energy resources, and in providing geologic control for the subsurface oil-related geologic analyses conducted by DOG.

- DNR Office of Project Management and Permitting (OPMP), with technical expertise during large project permitting.

- Division of Economic Development in the Department of Commerce, Community, and Economic Development (DCCED), to report on the status of Alaska's mineral industry.

- Division of Homeland Security \& Emergency Management (DHSEM; in the Department of Military and Veterans Affairs [DMVA]), and the Department of Environmental Conservation (DEC) to evaluate volcanic and other hazards, develop scenarios for hazards events, and update the State Hazard Mitigation Plan.

- Department of Transportation \& Public Facilities (DOT\&PF), University of Alaska Fairbanks (UAF), and other agencies to assess the impacts of landslides, slope failures, avalanches, flooding, erosion, and construction materials availability.

- Alaska Energy Authority (AEA) to evaluate hazards to proposed hydroelectric, geothermal, and other energy projects; to provide technical expertise on geothermal resource potential; and to evaluate resource potential around the state that might provide viable alternatives for energy development in rural Alaska.

- DNR Division of Mining, Land, and Water (DMLW) to evaluate groundwater issues and address land selection and sale questions.

In recent years, DGGS has also collaborated with the Alaska Natural Gas Pipeline project, Alaska Gasline Development Corporation (AGDC), and the State Pipeline Coordinator to assist in geologic data collection and hazards assessment for proposed natural gas pipelines.

DGGS also assists in large inter-division or other one-time efforts responding to special needs that are generally supported by interagency fund transfers. Smaller requests are funded by DGGS's annual general fund appropriation.

\section{Local Governments}

Many of the cooperative efforts implemented by DGGS with borough and municipal governments are conducted on a mutually beneficial but informal basis. For example, DGGS participates in a federally-funded cooperative program to develop tsunami-inundation maps for coastal communities. In communities for which inundation maps have been prepared in recent years, DGGS works closely with collaborators and city and borough governments to design project outputs to meet community needs for planning evacuation areas and routes.

DGGS works closely with local communities to help assess hazards and alternatives for mitigating the effects of erosion, flooding, and other surface processes that threaten their sustainability. DGGS also sends personnel to respond to natural disasters, such as the 
Sitka landslides in September 2015. Similarly, DGGS works with rural communities to help assess potential local energy resources as alternatives to diesel fuel. During volcanic unrest and eruption, DGGS, as a partner in the Alaska Volcano Observatory, communicates with local villages—as well as with industry sectors, the aviation community, and the military-to share information and observations of volcanic unrest.

\section{The University of Alaska}

DGGS has a longstanding and productive professional association with geoscientists and students at the University of Alaska. University of Alaska faculty often work as DGGS project team members on a wide range of collaborative research projects. University student interns are also an important part of the DGGS workforce; while working on DGGS projects, students learn a wide variety of geology-related skills. Some graduate students are able to apply their DGGS intern work to their thesis projects through research programs established through a Memoranda of Agreement with the University of Alaska, Fairbanks (UAF) Department of Geology \& Geophysics and Department of Mining \& Geological Engineering. DGGS and the university make frequent use of each other's libraries and equipment and University of Alaska faculty and students also frequent the Geologic Materials Center in Anchorage, where faculty conduct core logging classes. DGGS' Volcanology Section has a long-term cooperative relationship with the UAF Geophysical Institute, resulting from partnership in the Alaska Volcano Observatory.

\section{Federal Agencies}

DGGS has cooperative programs with numerous federal agencies including the U.S. Geological Survey (USGS), National Oceanic and Atmospheric Administration (NOAA), U.S. Fish and Wildlife Service (FWS), National Aeronautics and Space Administration (NASA), National Science Foundation (NSF), and periodically with the Federal Emergency Management Agency (FEMA), U.S. Department of Housing and Urban Development (HUD), the U.S. Bureau of Land Management (BLM) and the U.S. Department of Energy (DOE). In the past, DGGS has also engaged in cooperative programs with the U.S. Minerals Management Service (MMS), now the Bureau of Ocean Energy Management.

DGGS receives federal funds from matching grants for which the division must compete nationally with other organizations on a yearly basis. DGGS has been successful in securing federal funds to support mineral inventory mapping, surficial and earthquake hazardsrelated mapping, geologic-hazards evaluations, and studies related to oil and gas and geothermal potential. Although DGGS has historically been very successful in receiving federal grants and appropriations, the process is competitive and these funds are therefore project-specific or complementary to state-funded programs and do not replace state general fund support. Federal funding is pursued only for projects that advance and serve the division's statutory mission.

Two ongoing cooperative federal programs have provided support for key elements of the DGGS mission for many years. One is the Alaska Volcano Observatory (AVO) — a partnership established in 1988 consisting of USGS, DGGS, and the UAF Geophysical Institute. The USGS funds and administers the program for the purpose of providing a coordinated approach to mitigating volcano-hazard risks to the public, state infrastructure, and air commerce. The second ongoing program is the STATEMAP component of the National Cooperative Geologic Mapping Program, which was established by Congress in 1992 and is administered by the USGS. STATEMAP provides matching funds for geologic mapping projects according to priorities set by the Alaska Geologic Mapping Advisory Board (GMAB; see below).

DGGS has been successful in receiving cooperative agreements from the National Geological \& Geophysical Data Preservation Program (NGGDPP) and the National Cooperative Geologic Mapping Program (NCGMP). The NGGDPP, funded by the USGS, has supported several DGGS projects to preserve and make geologic information publicly available. STATEMAP funds provide a stable source of federal funding for geologic mapping in the state. 


\section{ALASKA GEOLOGIC MAPPING ADVISORY BOARD}

The Alaska Geologic Mapping Advisory Board (GMAB) guides DGGS in pursuing its goal of providing earth science information to the Alaska public. A number of prominent geologists and community leaders with a variety of backgrounds and a broad spectrum of experience in Alaska have agreed to serve on the advisory board. The board held its first meeting in Fairbanks on October 22, 1995 , and normally meets three times a year to discuss state needs, review DGGS programs, solicit and welcome comments and suggestions from the public, and provide recommendations to the state geologist.

This year, Dr. James Jones of the USGS was elected chair, and we thank Curt Freeman for his many years of service as chair, and welcome his continued involvement as a board member. In 2019, DGGS expanded the board membership, and welcomed Heidi Hansen of CIRI, and Rob Retherford of Alaska Earth Sciences to the board, bringing the number of board members to nine.

\section{Current members of the board are:}

\section{Steve Adamczak}

Vice President, Shannon and Wilson, Inc. Mr. Adamczak has more than 30 years of experience in geotechnical engineering, and represents the engineering geology and geotechnical community.

\section{Margaret Darrow}

University of Alaska Fairbanks, Department of Mining and Geological Engineering. Dr. Darrow has a background in engineering geology and represents the University, the Department and also the engineering geology discipline.

\section{Curt Freeman}

President, Avalon Development Corporation. Mr. Freeman runs a well-known and successful consulting mineral exploration firm in Fairbanks and represents minerals industry interests.

Janet Schaefer (AVO-ADGGS) walking along slopes of Kliuchef volcano, with older rocks of the Atka volcanic complex in the background. Photo. Michelle Coombs.

\section{Heidi Hansen}

Director, Lands \& Resources, Cook Inlet Region, Inc. (CIRI). Ms. Hansen has extensive experience in natural resource management and policy.

\section{Tom Homza}

Principal Regional Geologist, Shell Exploration and Production, Alaska. Dr. Homza has 20 years of oil and gas exploration experience and represents petroleum industry interests.

\section{James Jones, Chailr}

U.S. Geological Survey. Dr. Jones specializes in tectonic evolution and mineral resources with the USGS Anchorage office, and represents the Federal government, earthquake hazards, and mapping interests.

\section{Paull McCarthy}

Chair of the University of Alaska Fairbanks, Department of Geoscience. Dr. McCarthy has research interests in paleolandscape evolution, alluvial architecture, and nonmarine sequence stratigraphy. He represents the University of Alaska Fairbanks on the Board.

\section{Rob Retherford}

President, Alaska Earth Sciences. Mr. Retherford has decades of experience managing mineral exploration and geoscience projects in Alaska.

\section{Gregory Wilson}

Director, Arctic Exploration and Services, ConocoPhillips Alaska. Dr. Wilson has more than 25 years of oil and gas exploration experience in Alaska and also represents the oil and gas industry.

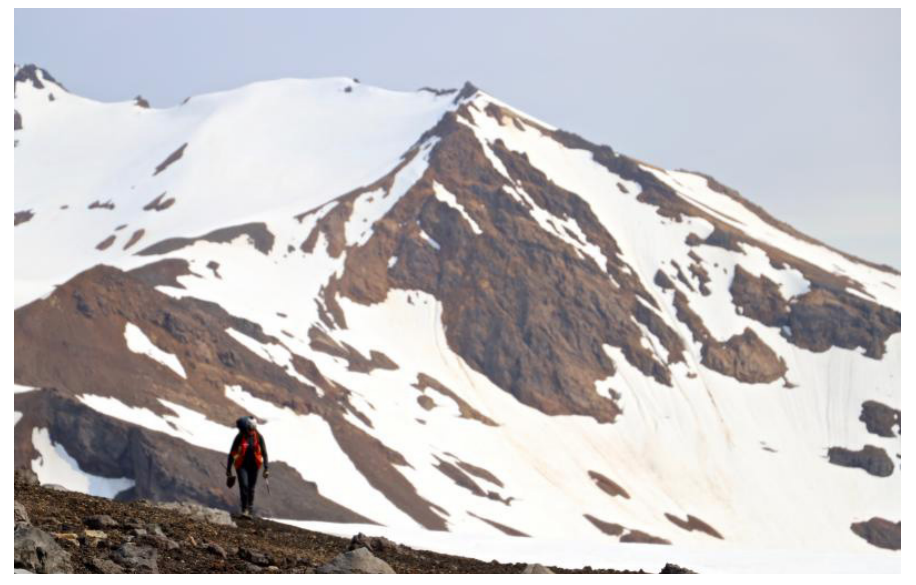




\section{DGGS MISSION AND HISTORY}

\section{Mission Statements}

Department of Natural Resources: Develop, conserve, and enhance natural resources for present and future Alaskans.

Division of Geological \& Geophysical Surveys: Determine the potential of Alaskan land for production of metals, minerals, fuels, and geothermal resources, the locations and supplies of groundwater and construction material; and the potential geologic hazards to buildings, roads, bridges, and other installations and structures (AS 41.08.020).

\section{History}

The present Division of Geological \& Geophysical Surveys (DGGS) evolved from Alaska's Territorial Department of Mines. That heritage is reflected in the Division's ongoing commitment to the application of geology to improve the welfare of Alaska citizens. The current name and mission of the Division were established in 1972 with the passage of Alaska Statute AS 41.08.

- Territorial Department of Mines, prior to 1959

- Division of Mines and Minerals, 1959-1966

- Division of Mines and Geology, 1966-1970

- Division of Geological Survey, 1970-1972

- Division of Geological \& Geophysical Surveys, 1972-Present

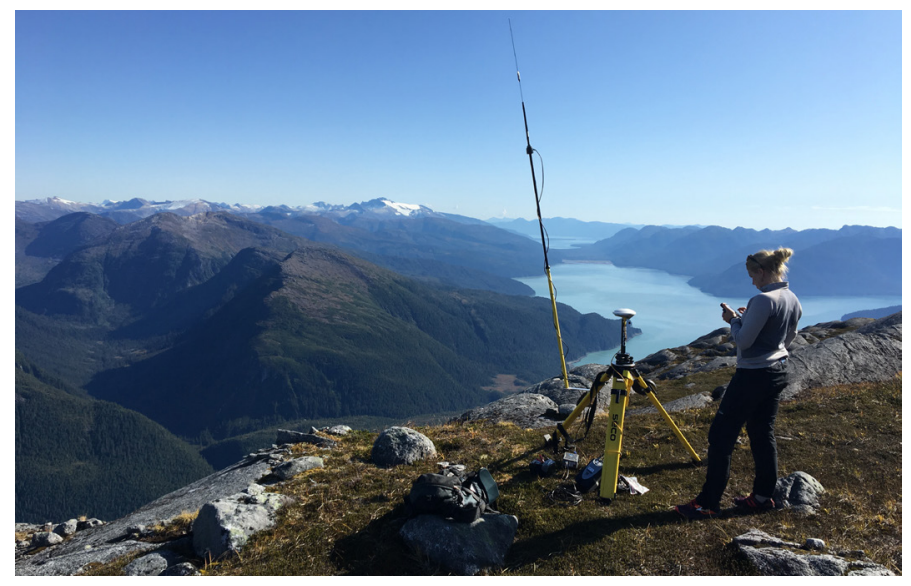

A DGGS scientist starts a GPS base station to serve an airborne lidar survey at Snettisham transmission line near Juneau, Alaska. Photo. Gabriel Wolken.

\section{Leadership}

Eleven qualified professional geoscientists have served as State Geologist:

- Jim Williams, 1959-1971

- William Fackler, 1971-1973

- Donald Hartman, 1973-1975

- Ross G. Schaff, 1975-1986

- Robert B. Forbes, 1987-1990

- Thomas E. Smith, 1991-1995

- Milton A. Wiltse, 1995-2002

- Rodney A. Combellick (Acting), 2003-2005

- Mark D. Myers, Feb.-Oct. 2005

- Robert F. Swenson, Nov. 2005-Nov. 2013

- Steven S. Masterman, Nov. 2013-present

By statute, the State Geologist serves as the Director of the Division of Geological \& Geophysical Surveys in the Department of Natural Resources (DNR) and is appointed by the DNR Commissioner. Since the early 1970s, State Geologists have been selected from lists of candidates prepared by the geologic community and professional societies in Alaska. A department order in 2002 formalized a process whereby the Geologic Mapping Advisory Board oversees evaluation of candidates and provides a list to the Commissioner. The qualifications and responsibilities of the State Geologist and the mission of DGGS are defined by statute.

\section{ORGANIZATION}

DGGS is one of seven divisions and six offices in the State of Alaska Department of Natural Resources. Under the overall administration of the Director's Office, the Division of Geological \& Geophysical Surveys is organized into five sections and the Geologic Materials Center (see organizational chart). The Division also administers the 11-member Alaska Seismic Hazards Safety Commission.

Current DGGS staff totals 36 permanent full-time professional and support positions, 1 permanent part time position, and additional nonpermanent staff and student interns. 


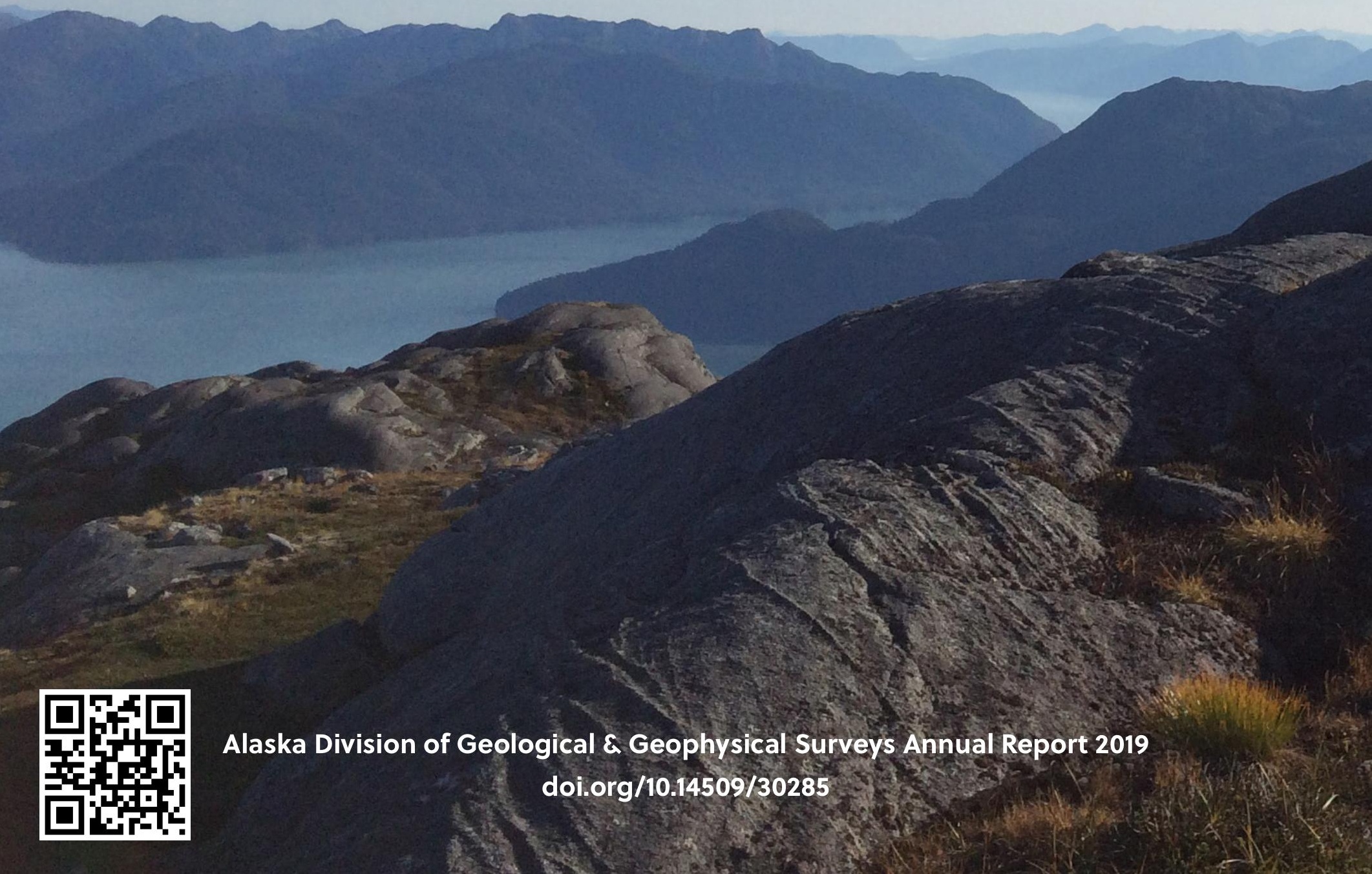

